\title{
Subpolar North Atlantic sea surface temperature since 6 ka BP: Indications of anomalous ocean-atmosphere interactions at 4-2 ka BP
}

\section{Lisa Claire Orme ${ }^{a}{ }^{*}$, Arto Miettinen ${ }^{a}$, Dmitry Divine ${ }^{\mathrm{a}, \mathrm{b}}$, Katrine Husum ${ }^{\mathrm{a}}$, Christof Pearce ${ }^{\mathrm{c}}$, Nicolas Van Nieuwenhove ${ }^{\mathrm{d}}$, Andreas Born ${ }^{\mathrm{e}, \mathrm{f}}$, Rahul Mohan ${ }^{\mathrm{g}}$, Marit-Solveig Seidenkrantz ${ }^{\mathrm{C}}$}

a Norwegian Polar Institute, Fram Centre, P.O. Box 6606 Langnes, 9296, Tromsø, Norway

${ }^{\mathrm{b}}$ Department of Mathematics and Statistics, Faculty of Science and Technology, The Arctic University of Norway, N-9037, Tromsø, Norway

' Centre for Past Climate Studies, Arctic Research Centre and iClimate, Department of Geoscience, Aarhus University, Høegh-Guldbergs Gade 2, building 1672, 213, 8000, Aarhus C, Denmark

${ }^{\mathrm{d}}$ Department of Earth Sciences, University of New Brunswick, 2 Bailey Drive Fredericton, NB, E3B 5A3, Canada

e Department of Earth science, University of Bergen, Postboks 7803, 5020, Bergen, Norway

${ }^{\mathrm{f}}$ Bjerknes Centre for Climate Research, University of Bergen, Postboks 7803, 5020, Bergen, Norway

${ }^{g}$ National Centre for Antarctic and Ocean Research, Ministry of Earth Sciences, Government of India, Headland Sada, Vasco-da-Gama, Goa, 403 804, India

\section{A R T I C L E I N F O}

\section{Article history:}

Received 2 May 2018

Received in revised form

20 June 2018

Accepted 2 July 2018

Available online 17 July 2018

\section{Keywords:}

Holocene

Paleoceanography

Paleoclimatology

North Atlantic

Micropaleontology

Diatoms

Sedimentology-marine cores

North Atlantic oscillation

East Greenland current

Sea surface temperature

\begin{abstract}
A B S T R A C T
Atmospheric circulation may change with future climate change in response to modification of meridional temperature gradients, but the potential influence on ocean circulation is as yet unclear. Over the mid-late Holocene, atmospheric circulation in the North Atlantic region has fluctuated on millennial timescales; therefore, the ocean response to these changes can be investigated using the paleoceanographic records that have been developed in the north-eastern subpolar North Atlantic. Here, we present a diatom-based sea surface temperature reconstruction from the Iceland Basin, south of Iceland; the reconstruction shows the warmest temperatures of the record at 6.1-4 ka BP, cooler temperatures at 4-2 ka BP and warmer temperatures thereafter. Inter-record comparisons indicate that the cold period at c. 42 ka BP may have resulted from a strengthened East Greenland Current and/or melting of the Greenland ice sheet, in response to a negative North Atlantic Oscillation. The findings highlight that atmospheric circulation changes are likely to cause pronounced variations in the latitudinal exchange of heat, which may have consequences for deep-water formation and global ocean circulation.
\end{abstract}

(C) 2018 Elsevier Ltd. All rights reserved.

\section{Introduction}

The dominant mode of variability in the atmospheric circulation of the North Atlantic region is the North Atlantic Oscillation (NAO). This index, calculated as the pressure gradient between the Subpolar Low, centred over Iceland, and the Azores High, controls the latitudinal position of storm tracks and wind strength in the North

\footnotetext{
* Corresponding author.

E-mail addresses: Lisa.Orme@npolar.no (L.C. Orme), Arto.Miettinen@npolar.no (A. Miettinen), Dmitry.Divine@npolar.no (D. Divine), Katrine.Husum@npolar.no (K. Husum), christof.pearce@geo.au.dk (C. Pearce), nicolas.vannieuwenhove@unb. ca (N. Van Nieuwenhove), Andreas.born@uib.no (A. Born), rahulmohangupta@ gmail.com (R. Mohan), mss@geo.au.dk (M.-S. Seidenkrantz).
}

Atlantic region (e.g. Hurrell and Van Loon, 1997). During Northern Hemisphere summer, the NAO generally weakens, with lower amplitude variability and a northward shift of the pressure cells, while they move southward and display a higher amplitude of variability in winter (Folland et al., 2009). A positive NAO (with the greatest difference between the pressure dipoles) is associated with a northward-shifted storm track, driving a stronger and northward-shifted North Atlantic Current (NAC) and potentially a greater E-W extension of the subpolar gyre (SPG; Taylor and Stephens, 1998; Curry and McCartney, 2001; Frantantoni, 2001), although this latter response has been questioned (Foukal and Lozier, 2017). Weaker and southward-shifted storm tracks occur during negative NAO phases (characterised by a reduced pressure difference), resulting in a weaker and southward-shifted NAC 
(Taylor and Stephens, 1998; Curry and McCartney, 2001).

During a positive (negative) NAO, over sub-annual timescales, the response to air-sea heat fluxes and wind-driven Ekman transport is cooling (warming) in a zonal band spanning the North Atlantic north of $45^{\circ} \mathrm{N}$ (Kushnir, 1994; Seager et al., 2000; Visbeck et al., 2003). However, over multi-annual to decadal/centennial timescales it is suggested that a positive (negative) NAO causes increased (decreased) convective activity in the Labrador Sea and strengthening (weakening) of the SPG and meridional overturning circulation, resulting in warming (cooling) north of $55^{\circ} \mathrm{N}$ (Eden and Jung, 2001; Visbeck et al., 2003; Häkkinen and Rhines, 2004; Latif et al., 2006). During a negative NAO strengthened northerly winds to the east of Greenland can reinforce the East Greenland Current (EGC) and increase the export of sea ice and freshwater from the Arctic to the North Atlantic, a scenario which in the twentieth century caused 'Great Salinity Anomalies' (Dickson et al., 1996: Delworth et al., 1997; Belkin et al., 1998; Blindheim et al., 2000; Ionita et al., 2016). Similar episodes have been identified over decadal-centennial timescales in model and paleoclimate analyses (Delworth et al., 1997; Renssen et al., 2005; Sicre et al., 2008; Ran et al., 2011). Nevertheless, the interactions between the ocean and atmosphere are complex. Models indicate that, due to the coupling of the ocean and atmosphere system, sea surface temperature (SST) changes themselves may force NAO variability. Here, potential feedbacks include changes in heat transport by the subtropical gyre (STG) and the SPG (Bellucci et al., 2008) as well as changes in evaporation, precipitation and atmospheric heating processes (Rodwell et al., 1999).

The NAO is also negatively correlated with atmospheric temperatures over the Greenland ice sheet and is therefore a potentially important factor controlling past and future melting (Serreze et al., 1997; Chylek et al., 2004; Fettweis et al., 2013). The melting of the Laurentide ice sheet in the early Holocene is known to have lowered SSTs in this region (Andersen et al., 2004b; Berner et al., 2008; Blaschek and Renssen, 2013; Jiang et al., 2015; Sejrup et al., 2016), however there has been less research on the ocean temperature response to fluctuations in the extent of the Greenland ice sheet during the mid to late Holocene (Briner et al., 2016).

Compilations of SST reconstructions from the subpolar North Atlantic show that during the mid-late Holocene the dominant feature in the region was cooling (e.g. Calvo et al., 2002; Rimbu et al., 2003; Sundqvist et al., 2014; Sejrup et al., 2016), which was primarily thought to result from orbital forcing (e.g. Andersen et al., 2004a, 2004b; Renssen et al., 2005; Hald et al., 2007; Berner et al., 2008; Kissell et al., 2013; Jiang et al., 2015; Sejrup et al., 2016). However, reconstructions indicate differences between regions, as there is also some evidence for a warming after $2 \mathrm{ka}$ BP in the Iceland and Greenland Seas (e.g. Justwan et al., 2008; Miettinen et al., 2012; Telesiński et al., 2014; Moossen et al., 2015; Sejrup et al., 2016; Kristjánsdóttir et al., 2017). Thus, understanding the past oceanographic changes is complex due to differences between reconstructions from the same region and even the same site, which may result from real spatial patterns but also factors related to the specific proxy used for the different SST reconstructions (climate-sensitivity, seasonal growth and habitat water-depth, as well as the statistical methods used).

Our understanding of the NAO variability during the Holocene is based on just a few records. Trouet et al. (2009) and Faust et al. (2016) suggest that the Medieval Climate Anomaly ( 950-1250 A.D.) had a persistent positive NAO and the Little Ice Age (1250/ 1400-1850 A.D.) a negative NAO, and an imprint of these changes has been found in some marine reconstructions (e.g. Abrantes et al., 2005; Seidenkrantz et al., 2007, 2008; Sicre et al., 2014). Longer NAO reconstructions indicate that beginning at 6-4.5 ka BP until 2 ka BP the NAO was more neutral and negative, which was followed by a more frequently positive NAO after 2 ka BP (Olsen et al., 2012; Nesje et al., 2000; Faust et al., 2016), a trend supported by a compilation of SST reconstructions (Rimbu et al., 2003). The validity of basing NAO reconstructions on single sites has been questioned due to non-stationarity in the proxy-NAO relationship through time (e.g. Lehner et al., 2012; Ortega et al., 2015). However, the NAO reconstructions are supported by storm track reconstructions from Europe, which show a southward storm track position (reflecting a more negative NAO) before $2 \mathrm{ka} \mathrm{BP}$, followed by a northward storm track shift (reflecting a more positive NAO pattern) after 2 ka BP (Bakke et al., 2008; Orme et al., 2017). These results therefore suggest that through the Holocene there have been long-term millennial shifts in atmospheric circulation.

The CMIP5 multi-model ensemble predicts that up until the end of the 21st century, storm tracks will stay within the range of natural variability in the northern hemisphere, although there is substantial uncertainty in this prediction (Collins et al., 2013). However, some studies based on modelling, observational and palaeoclimate records (Francis and Vavrus, 2012; Yang and Christensen, 2012; Kim et al., 2014; Orme et al., 2017) suggest that greater warming over the polar regions compared to that of the mid-latitudes could weaken the temperature gradient, driving a weaker meridional circumpolar circulation and a negative NAO. Such negative NAO circulation may result in changes in the subpolar North Atlantic, by reducing the amount of wind-driven northward heat transport, increasing the southward export of Arctic water and altering ocean-atmosphere heat fluxes, which may then alter rates of deep-water formation and the wider ocean circulation (e.g. Taylor and Stephens, 1998; Blindheim et al., 2000; Curry and McCartney, 2001; Eden and Jung, 2001; Latif et al., 2006). Thus, a central aim of this paper is to investigate the changes to the North Atlantic Ocean circulation that occurred as a result of the possible long-term negative phase of the NAO at 4-2 ka BP (Olsen et al., 2012; Faust et al., 2016). As such, here we present a new diatom-based SST reconstruction from the Iceland Basin for the last $6.1 \mathrm{ka}$ BP and compare this with other SST reconstructions from the subpolar North Atlantic to understand the spatial temperature patterns. We then compare these with past variations in atmospheric circulation, to better understand the long-term ocean-atmosphere interactions in a region of high importance for the global climate system.

\section{Oceanographic setting}

The core site DA12-11/2-GC01 is located in the Iceland Basin which is bounded by the Reykjanes Ridge to the west, Iceland and the Iceland-Faroe ridge to the north and northwest and the Rockall Plateau to the southwest (Fig. 1). Within the Iceland Basin sediment transported by deep currents has accumulated to form the Björn and Gardar Drifts (Bianchi and McCave, 2000).

The NAC transports warm Atlantic water to the subpolar North Atlantic along several pathways (Fig. 1). A western branch turns northwest towards Iceland; part of the current passes over the Iceland-Faroe Ridge into the Nordic Seas while the other part travels as the Irminger Current (IC) first to the south and then to the north around the Reykjanes Ridge (Jakobsen et al., 2003; Pollard et al., 2004). The IC bifurcates in the Denmark Strait with a small part flowing to the north of Iceland while a larger branch recirculates to the south and converges with the south flowing EGC (Jakobsen et al., 2003; Pollard et al., 2004; Våge et al., 2011). The eastern branch of the NAC remains close to the European continental slope as it heads northwards, passing through the Rockall Trough to the Faroe-Shetland channel before entering the Nordic Seas (Orvik and Niiler, 2002; Jakobsen et al., 2003). The two currents that entered the Nordic Seas head northwards along separate 


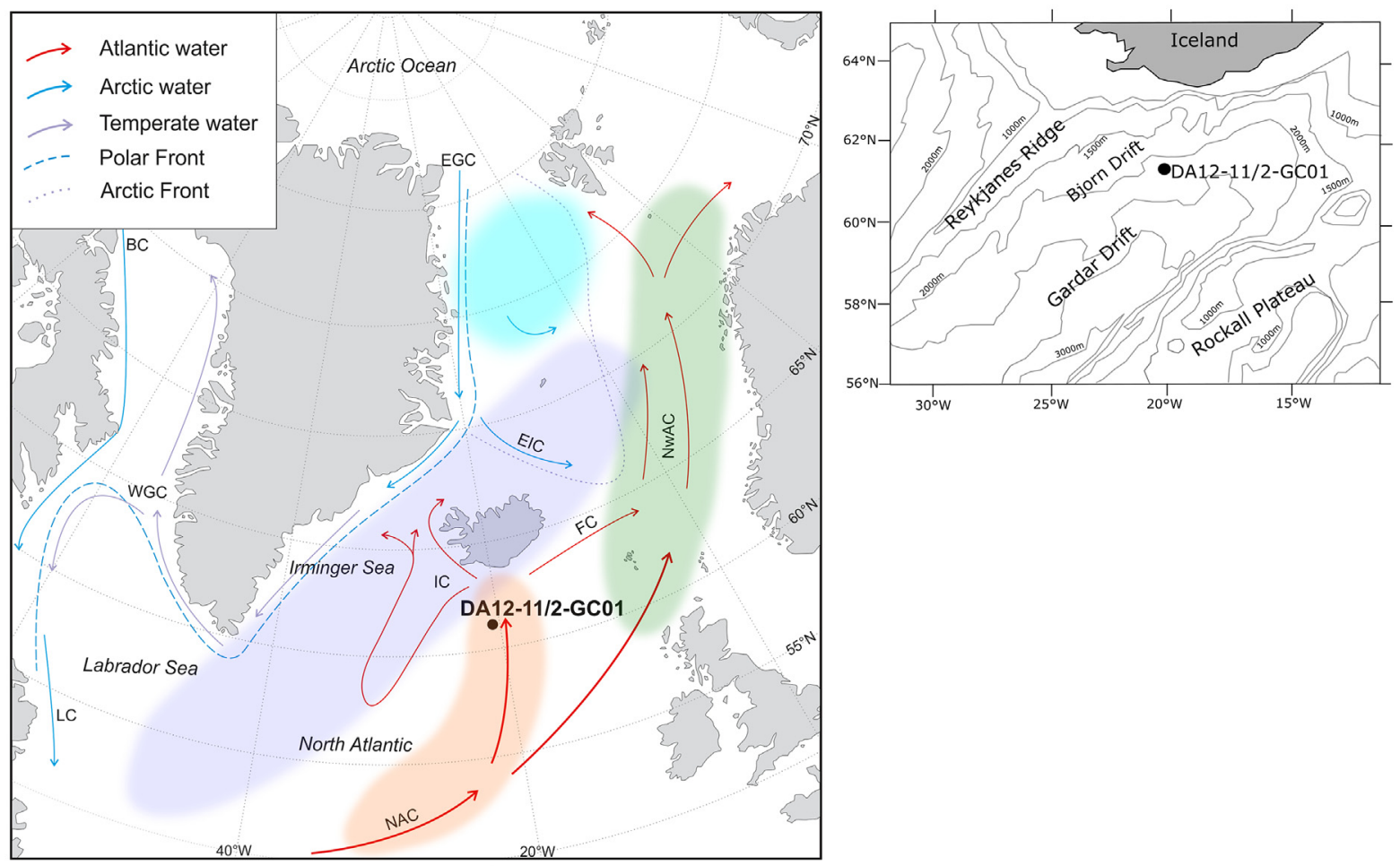

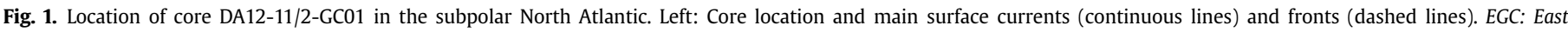

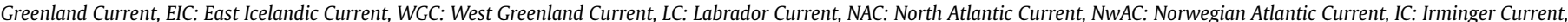

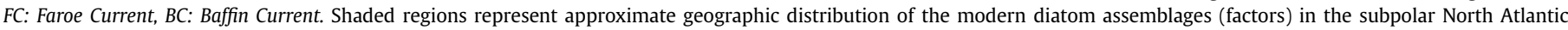

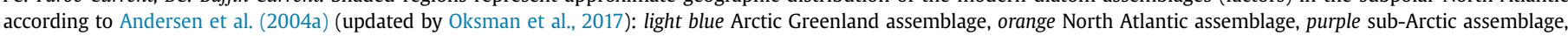

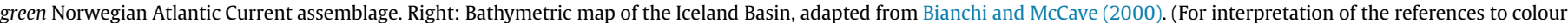
in this figure legend, the reader is referred to the Web version of this article.)

paths, with an area of $200-600 \mathrm{~km}$ between them occupied by Atlantic Water (Orvik and Niiler, 2002). The warm water of the NAC is transported to Svalbard, where it forms the West Spitsbergen Current (Aagaard and Greisman, 1975).

The northward transport of warmer Atlantic water is balanced by the southward transport of cold, low salinity water (polar surface water) and sea ice from the Arctic Ocean, carried by the EGC, which passes through the Fram Strait and continues southwards through the Denmark Strait (Aagaard and Carmack, 1989; Martin and Wadhams, 1999; Woodgate et al., 1999; Rudels et al., 2002). The Polar Surface Water of the EGC extends from the surface to depths $\sim 150 \mathrm{~m}$, with temperatures $\sim 1.7^{\circ} \mathrm{C}$ and low salinity (34\%o) (Aagaard and Coachman, 1968; Jeansson et al., 2008).

The SST distribution in the Iceland Basin is characterised by a gradient, with warmer temperatures towards the southwest and cooler temperatures towards Iceland and the Reykjanes Ridge (De Boisséson et al., 2010). The surface water masses are typically associated with Subpolar Mode Water, which has temperature and salinity varying in the range of $7-12{ }^{\circ} \mathrm{C}$ and $35-35.5 \%$ respectively and results from mixing of subpolar and subtropical waters advected to the Iceland Basin by the NAC (Wright and Worthington, 1970; McCartney and Talley, 1982; De Boisséson et al., 2012).

\section{Materials and methods}

\subsection{Core location}

The $419.5 \mathrm{~cm}$ long marine sediment core DA12-11/2-GC01 was recovered in September 2012 by the Danish R/V Dana during the
DA12-11/2 teaching cruise, using a gravity corer. The core was taken from a location at the northern edge of the Gardar Drift and the eastern edge of the Björn Drift in the Iceland Basin $\left(61.36 .536{ }^{\circ} \mathrm{N}\right.$, 20.42.164 ${ }^{\circ} \mathrm{W}$; Fig. 1) at a water depth of $2120 \mathrm{~m}$. Due to bad weather, it was not possible to retrieve a CTD depth profile at the site, but in the upper $50 \mathrm{~m}$ of the water column the average temperature at the site for the period $1955-2012$ was $10.9 \pm 1{ }^{\circ} \mathrm{C}$ in summer and $8.1 \pm 0.8{ }^{\circ} \mathrm{C}$ in winter, while the salinity was $35.15 \pm 0.08 \%$ in summer and $35.23 \pm 0.04 \%$ in winter (WOA2013; Locarnini et al., 2013; Zweng et al., 2013).

\subsection{Age-depth model}

The age-depth model of the full core is based on 10 AMS ${ }^{14} \mathrm{C}$ radiocarbon dates of either planktic foraminiferal tests (Globigerina bulloides, Turborotalita quinqueloba) or shell fragments (holoplanktic thecosome pteropod Diacria trispinosa) (Van Nieuwenhove et al., 2018). The results from the upper $2 \mathrm{~m}$ of core presented here (Fig. 2) are constrained by six radiocarbon dates, including date AAR24460 from $235 \mathrm{~cm}$, which has a modelled age of 7540 cal yrs BP (Van Nieuwenhove et al., 2018). Samples were dated at the Aarhus AMS Centre of the Department of Physics and Astronomy, Aarhus University. The radiocarbon ages were calibrated and the age-depth model developed with OxCal 4.2 (Bronk Ramsey, 2009) using the Marine13 calibration curve (Reimer et al., 2013), with a regional marine reservoir age offset $\Delta R=0$ years (Van Nieuwenhove et al., 2018). Four pronounced tephra layers could not be attributed to eruptions unambiguously so they were not used to constrain the age-depth model, and the layers 


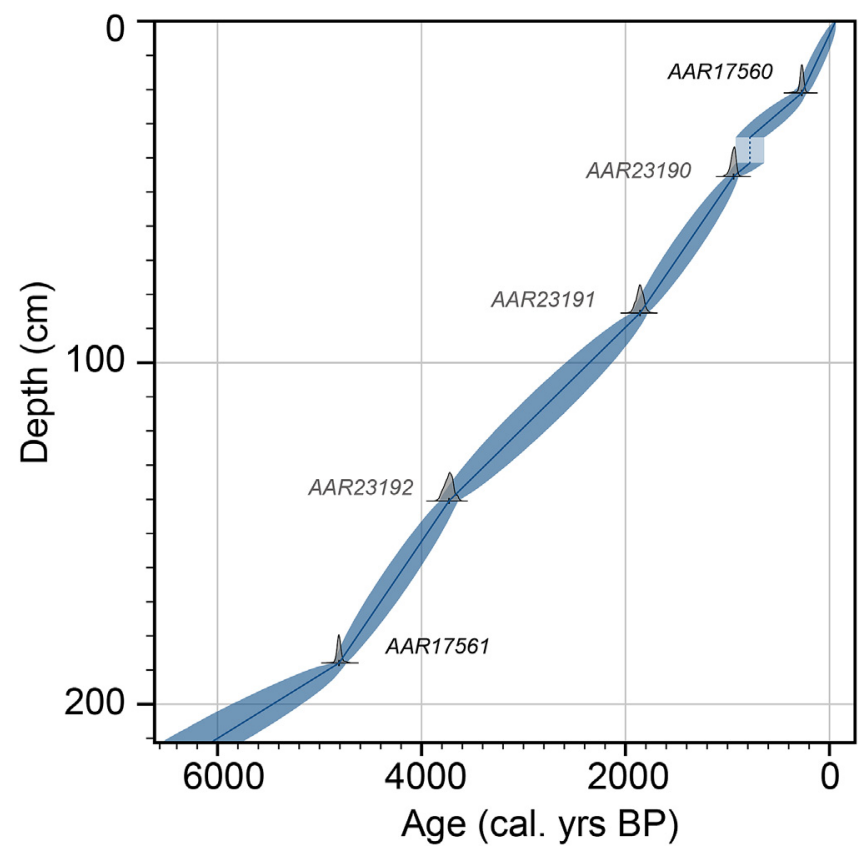

Fig. 2. Age-depth model for the upper $210 \mathrm{~cm}$ of the DA12-11/2-GC01 core. The calibrated median age is shown as the dark blue curve, the blue shading shows the 1sigma probability interval. Radiocarbon dates are plotted as probability distributions and the AMS laboratory codes are listed for each date. The dashed line around $35 \mathrm{~cm}$ depth shows a tephra layer, which is assumed to represent an instantaneous deposit (Van Nieuwenhove et al., 2018). (For interpretation of the references to colour in this figure legend, the reader is referred to the Web version of this article.)

containing ash were excluded from the age model assuming an instantaneous sedimentation. As the surface sediment was not dated, the ages for the interval $0-21 \mathrm{~cm}$ depth were estimated by interpolation between the upper radiocarbon date and the coring year 2012 A.D.. The development of the age-depth model is described in full by Van Nieuwenhove et al. (2018).

\subsection{Diatom analysis and SST reconstruction}

The uppermost $210 \mathrm{~cm}$ of the core representing the last $6.1 \mathrm{ka}$ cal BP (Fig. 2) was analysed for diatoms at $5 \mathrm{~cm}$ intervals giving an average temporal resolution of 145 years. The diatoms were isolated from the sediment sample following the methods of Koç et al. (1993). The process involves the removal of the organic and carbonate material from the sample through treatment with $\mathrm{HCl}$ and $\mathrm{H}_{2} \mathrm{O}_{2}$, removal of the clay fraction and mounting of the remaining sample onto slides. Analysis of the diatom assemblages was carried out on a Leica Orthoplan microscope using $1000 \times$ magnification and followed the counting protocol outlined by Schrader and Gersonde (1978). A minimum of 300 diatom frustules were identified in each sample and the percentage abundance of each sample calculated. The 300 counted frustules did not include Chaetoceros spores, which are highly abundant and insensitive to SST (KoçKarpuz and Schrader, 1990).

Diatoms in the North Atlantic bloom during the spring-summer season; therefore, the species variability represents summer conditions and particularly August temperature (Koç-Karpuz and Schrader, 1990; Birks and Koç, 2002; Berner et al., 2008). Past SSTs are reconstructed using transfer functions, which establish the relationship between diatom species assemblages present in the surface (modern) ocean sediments and the known, modern SST from the sample locations. Individual diatom species have a unimodal relationship with temperature (i.e. a maximum abundance at an optimum temperature), but SST can be predicted because the optimum temperatures of different species are distributed along a linear temperature gradient (Birks, 1998; Berner et al., 2008). The direct relationship between the upper water temperature and surface diatom community and the preserved fossil community at a given location is complicated by the potential for lateral transport of sinking diatoms. Individual diatoms or aggregates sink relatively slowly $(0.1-100 \mathrm{~m} /$ day $)$, so may be carried long distances, while those within faecal pellets sink quickly (5-2700 m/day; Turner, 2002; Sarthou et al., 2005; Miklasz and Denny, 2010), so deposition is more direct. However the contribution of each to the diatoms on the seafloor is generally unknown and spatially variable (Turner, 2002). Nevertheless, the wellestablished strong relationship between the summer temperatures and fossil diatom assemblages in surface sediments supports that in general diatom deposition in the subpolar North Atlantic occurs locally.

The relative diatom abundances were converted to summer (August) SST using the North Atlantic diatom calibration data set consisting of 183 surface sediment samples (Miettinen et al., 2015) and a weighted averaging partial least squares (WA-PLS) transfer function (ter Braak and Juggins, 1993). Using WA-PLS, the fossil down-core diatom assemblages can then be used to estimate the past SST (e.g. Birks and Koç, 2002). The WA-PLS transfer function utilizes the unimodal species response model and attempts to maximize the covariance between the modern diatom assemblages and SST, in order to maximize the predictive power of the model (Birks and Koç, 2002) and this requires the number of components that the model will use to be specified. The optimal number of WAPLS components was determined using a randomization $t$-test applied to h-block prediction errors, which showed that the 2component model is the most reliable (Oksman et al., 2017). The proxy error for the SST reconstruction was estimated using the hblock cross validation technique (Trachsel and Telford, 2016), a method which accounts for spatial autocorrelation (and the resulting underestimation of error) by excluding from the calibration dataset samples closer than a certain distance from the core site (Oksman et al., 2017). The root mean square prediction error (RMSEP) for the 2-component WA-PLS model with the h-block cross validation is $1.1^{\circ} \mathrm{C}, \mathrm{R}^{2}$ (the coefficient of determination between observed and inferred values) is 0.92 and maximum bias is $2.8^{\circ} \mathrm{C}$.

Factor analysis was conducted to characterise past oceanographic conditions at the core site in terms of variations in prevalent types of surface water masses. Q-mode factor analysis on the modern diatom calibration dataset from the North Atlantic has grouped diatom taxa into a number of assemblages (or factors) that are characteristic of different water masses (Imbrie and Kipp, 1971; Andersen et al., 2004a; Oksman et al., 2017). These are the Arctic Greenland Assemblage (factor 1), North Atlantic Assemblage (factor 2), sub-Arctic Assemblage (factor 3), Norwegian Atlantic Current Assemblage (factor 4), Sea Ice Assemblage (factor 5), Arctic Assemblage (factor 6), East and West Greenland Current Assemblage (factor 7), and the Mixed Water Masses Assemblage (factor 8) (Andersen et al., 2004a). This classification of assemblages has since been modified by Oksman et al. (2017) who used the extended modern core top calibration data set (183 samples rather than 139) and renamed the Sea Ice assemblage as the Marginal Ice Zone assemblage. This modified classification of assemblages was applied to the DA12-11/2-GC01 diatom record to show the relative importance of each factor, and therefore each water mass, through time. The communality is used to assess the agreement between the factor analysis and fossil assemblages. It is defined as a squared sum of factor loadings, which is actually a fraction of variance represented by the 
decomposition for every single sample analysed. Ideally it should be 1 , but in reality it is generally lower.

\section{Results}

The diatom species assemblage of DA12-11/2-GC01 is dominated by common North-Atlantic temperate species Thalassionema nitzschioides, Rhizosolenia hebetata f. semispina, Rhizosolenia borealis, Proboscia alata, Thalassiosira oestrupii, Nitzschia bicapitata and Synedra sp. (each $>5 \%$ abundance) (Fig. 3). The reconstruction suggests an average summer SST of about $12^{\circ} \mathrm{C}$ (range $11.2-13.3^{\circ} \mathrm{C}$ ) (Fig. 4).

The reconstruction shows a weak negative SST trend through the whole record with a cooling of around $0.1^{\circ} \mathrm{C} / 1000$ years (Fig. 4). This was likely associated with decreasing abundances of warm species (Thalassiosira oestrupii, Thalassionema nitzschioides and perhaps Thalassiosira angulata, which have optimum temperatures of $13.4,11.1$ and $9{ }^{\circ} \mathrm{C}$ respectively), and increasing abundances of cool species (Rhizosolenia hebetata f. semispina and Thalassiosira gravida, which have optimum temperatures of 8.4 and $7.1^{\circ} \mathrm{C}$ respectively) (Fig. 3).

The millennial-scale variations in temperature are pronounced and show three distinct periods, with cooler SSTs at $\sim 4-2 \mathrm{ka}$ BP and warmer SSTs before ( 6.1-4 ka BP) and after (2-0 ka BP) this interval (Fig. 4). Given the age model uncertainties, the inferred cold period could span up to $2.4 \mathrm{ka}$, covering the time interval of 4.2 to $1.8 \mathrm{ka}$ BP. The earliest warm period at $\sim 6.1-4 \mathrm{ka}$ BP had average reconstructed SSTs of $12-13.3^{\circ} \mathrm{C}$, with the warmest temperatures in the record occurring at $\sim 6.1-5.5 \mathrm{ka} \mathrm{BP}\left(\mathrm{c} .13^{\circ} \mathrm{C}\right.$ ). The cooler period $\sim 4-2$ ka BP had reconstructed SST that varied around $11.5^{\circ} \mathrm{C}$, with minima at 3.2 and $2.4 \mathrm{ka}$ BP interrupted by a short warming at $2.7 \mathrm{ka}$ BP. In the most recent period after $2 \mathrm{ka}$ BP the SSTs again increased peaking at $1.8 \mathrm{ka}$ BP, yet SSTs did not attain values as high as those reconstructed for 6.1-4 ka BP. The low SSTs calculated for
4-2 ka BP are linked to a reduced abundance of the warm Synedra sp. (optimum temperature $12.7^{\circ} \mathrm{C}$ ), and increased abundance of species that prefer cooler waters (Thalassiotrix longissima, Thalassiosira nodulolineata, Rhizosolenia hebetata f. semispina and Asteromphalus robustus; optimum temperatures of 8.5, 7.0, 8.4 and $5.1^{\circ} \mathrm{C}$ respectively) (Fig. 3). After $2 \mathrm{ka} \mathrm{BP}$ the increased abundance of Synedra species and reduced abundances of those cooler water species support a return to warm SSTs.

The significance of the temperature change at 4-2 ka BP compared to the rest of the record was tested statistically using a 2sample Students $t$-test. This tested the null hypothesis that the results originated from two normal distributions with equal means and non-equal unknown variances. Prior to testing, the reconstructed SST values grouped into these two subsets were perturbed with an additive noise term of N (0,RMSEP). In total, 2000 perturbed reconstructions were generated. The test statistics for each pair member were then collected and analysed. Results demonstrated a rejection rate for the null hypothesis of about $44 \%$, suggesting that we can reject the hypothesis that the average SST at 4-2 ka BP was equal to the average SST over the rest of the reconstruction.

The factor analysis showed that three diatom assemblages were dominant in the fossil data set; the Norwegian Atlantic Current assemblage, the sub-Arctic assemblage and the North Atlantic assemblage (Fig. 5). The down core distribution of the dominant factors reflects the time variability of the reconstructed SST and presumably the relative contributions of different water masses (as shown in Fig. 1) at the core location. The Norwegian Atlantic Current (factor 4) showed increasing values at 6.1-4.9 ka BP, constant values until $2 \mathrm{ka} B P$ before slightly reduced and variable values after 2 ka BP, with a prominent minimum at $0.1 \mathrm{ka}$ BP. The sub-Arctic assemblage (factor 3 ) shows an increasing trend through the entire record from $6.1 \mathrm{ka} B \mathrm{BP}$ to present, with elevated values at 4-2, 1 and 0.1 ka BP (Fig. 5). The North Atlantic Assemblage (factor 2)
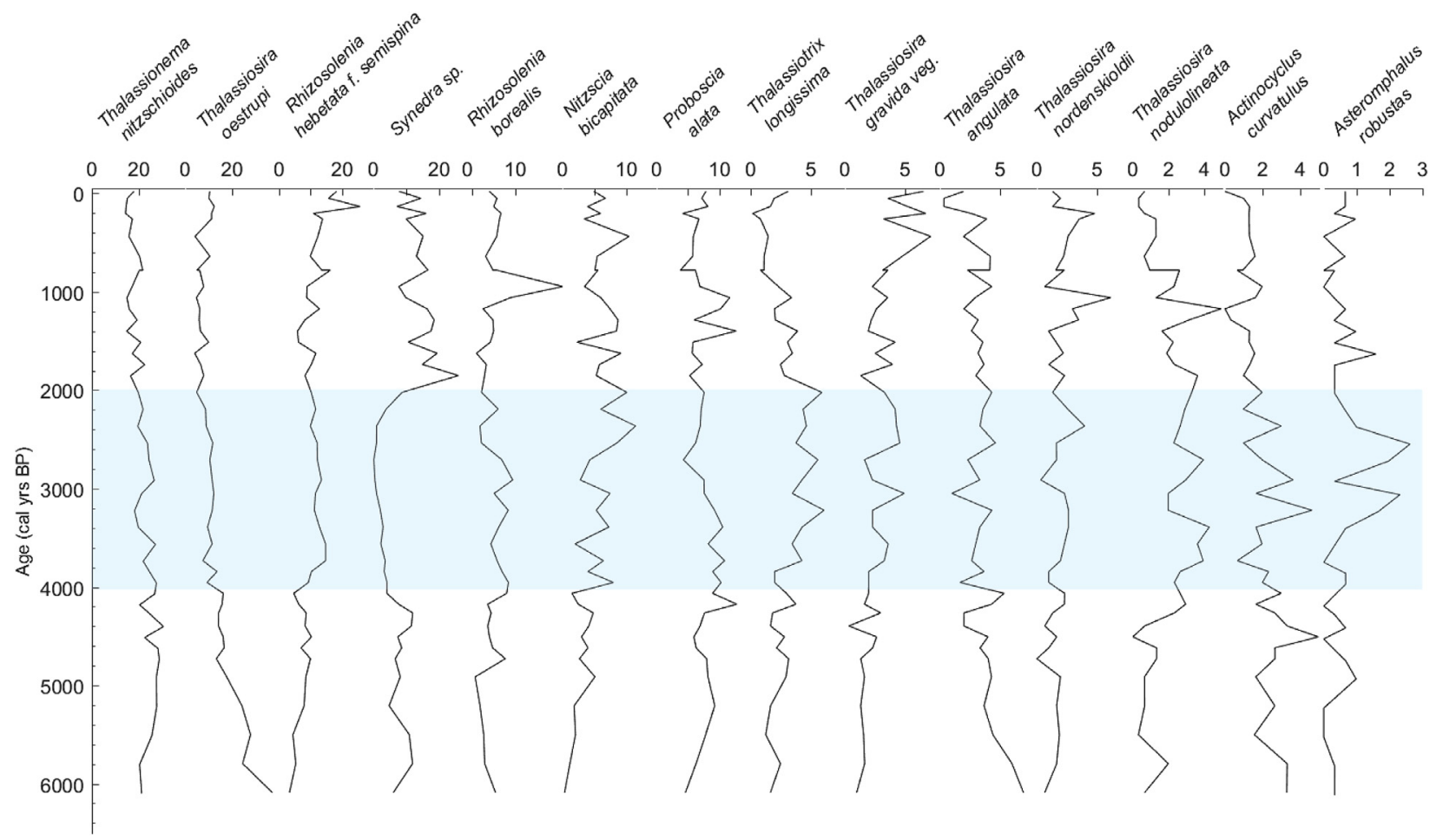

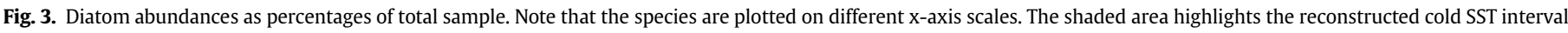
at c.4-2 ka BP. 

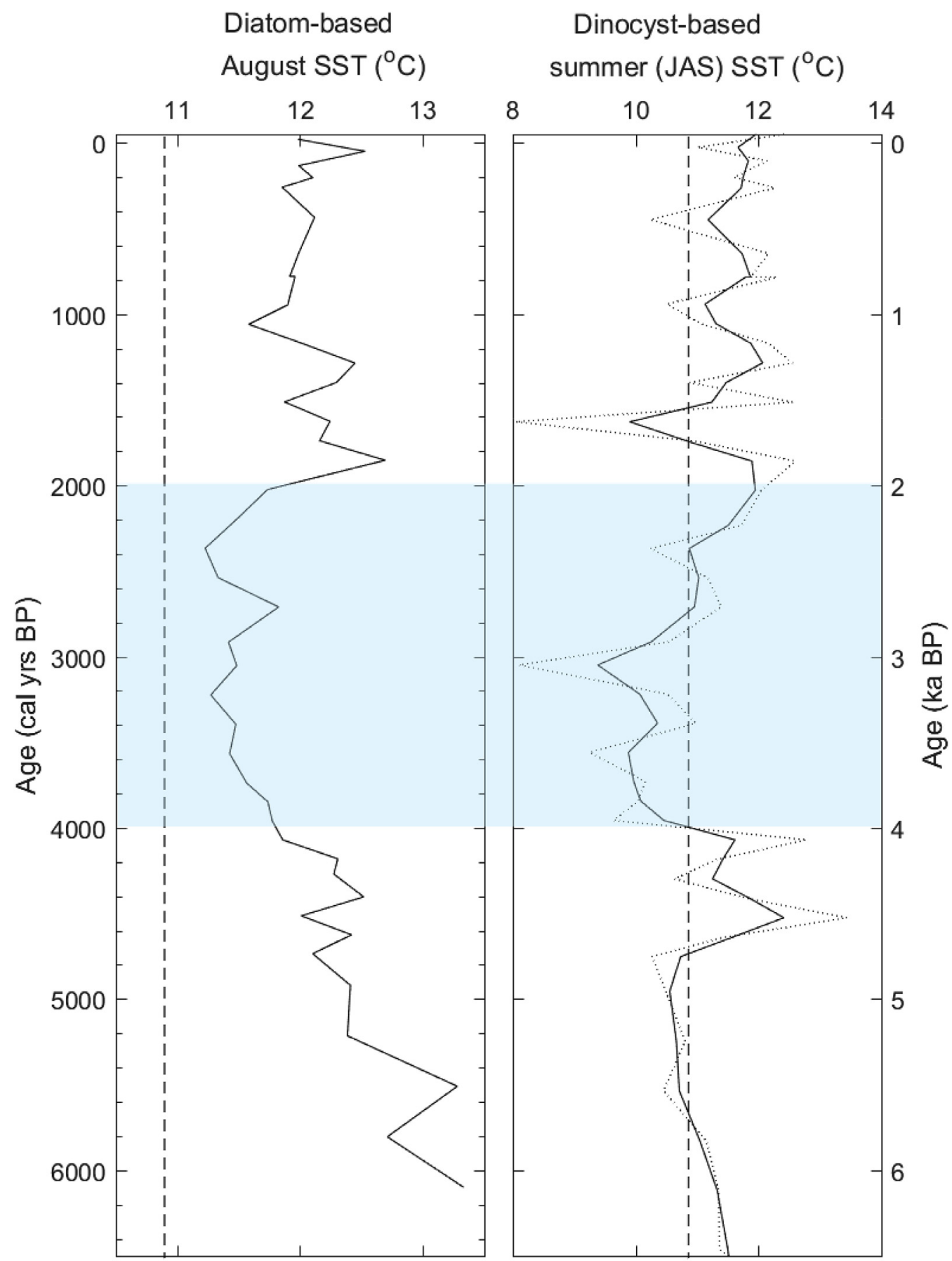

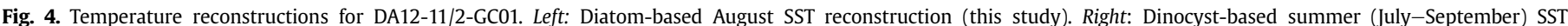

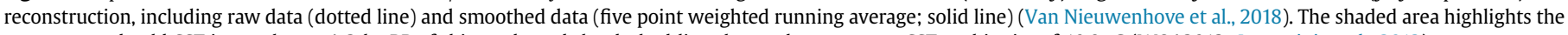
reconstructed cold SST interval at c. 4-2 ka BP of this study and the dashed line the modern summer SST at this site of $10.9{ }^{\circ} \mathrm{C}($ WOA2013; Locarnini et al., 2013).

shows a persistent negative trend between 6.1 and $2 \mathrm{ka}$ BP, thereafter remaining constant (Fig. 5). High values of the communality index before $2 \mathrm{ka}$ BP support that the fossil assemblages were similar to the modern assemblages used for the factor analysis (Fig. 5). The decrease after this point indicates that during the last 2000 years the fossil assemblages were not as strongly similar to those found in the modern assemblages. We speculate that this may be due to mixing of different water masses after $2 \mathrm{ka} B P$ or due to relatively few modern samples from the Iceland Basin in the modern calibration dataset.

\section{Discussion}

\subsection{Sea surface temperature in the Iceland basin}

The millennial trends in SST observed in the diatom-based August SST reconstruction presented here are supported by a summer SST reconstruction based on dinoflagellate cysts from the same core (Fig. 4; Van Nieuwenhove et al., 2018), which also shows a cold interval between 4 and $2 \mathrm{ka}$ BP. In the diatom-based record the mean reconstructed temperature between 4 and $2 \mathrm{ka}$ BP is 


\section{Norwegian Atlantic Current North Atlantic Sub-Arctic Assemblage Communality Assemblage Assemblage}

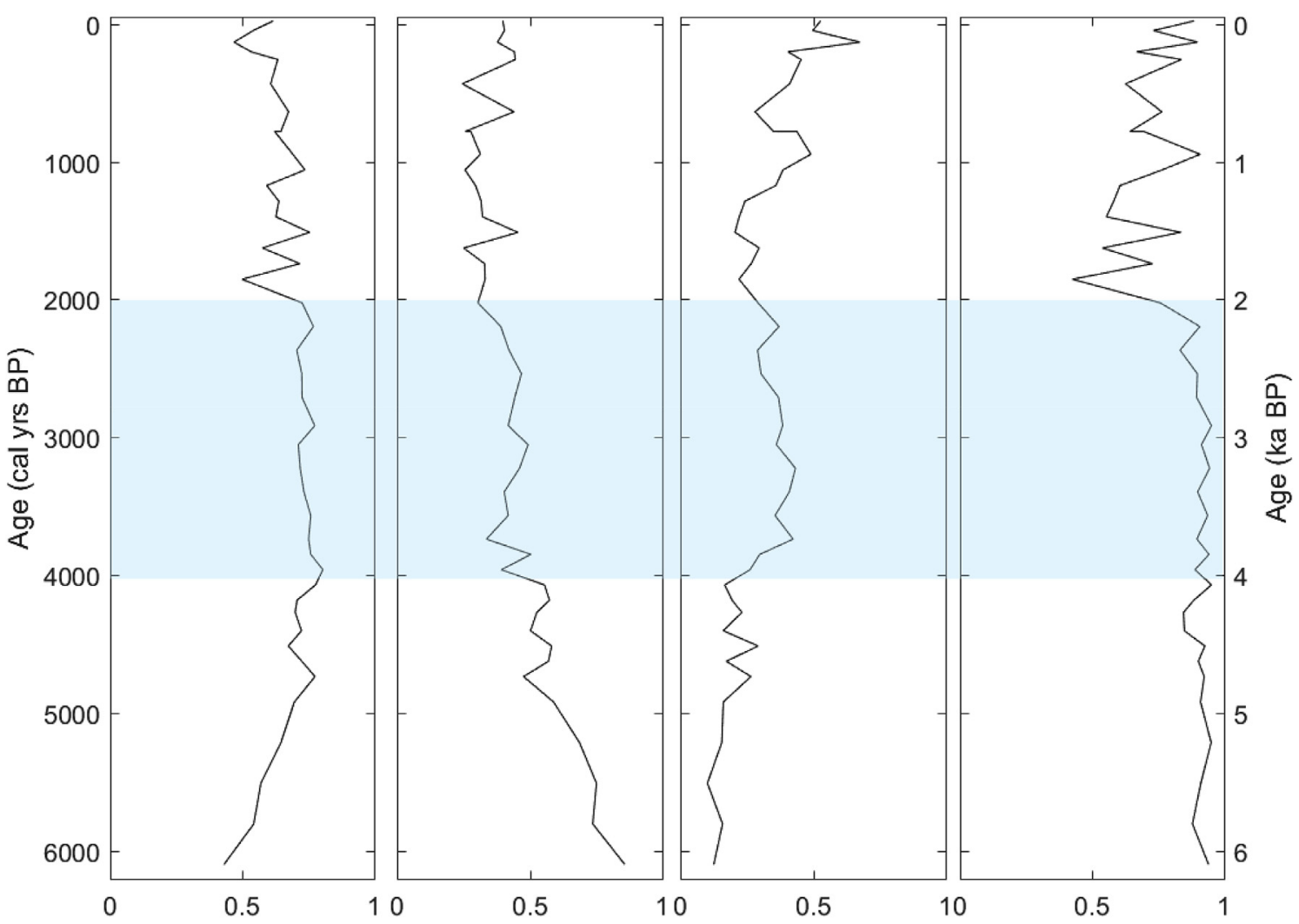

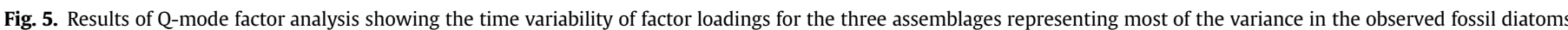

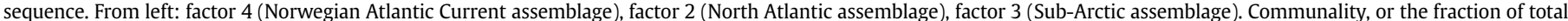

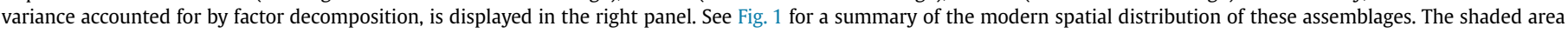
highlights the reconstructed cold SST interval at c. 4-2 ka BP of this study.

$11.5^{\circ} \mathrm{C}$ compared with 12.5 and $12.1^{\circ} \mathrm{C}$ in the periods before 4 ka BP and after 2 ka BP respectively, showing a reconstructed cooling of $0.6-1{ }^{\circ} \mathrm{C}$. In the dinocyst-based record the mean reconstructed temperature between 4 and $2 \mathrm{ka} \mathrm{BP}$ is $10.3^{\circ} \mathrm{C}$ compared with 11.3 and $11.6^{\circ} \mathrm{C}$ in the periods before $4 \mathrm{ka} \mathrm{BP}$ and after $2 \mathrm{ka} \mathrm{BP}$ respectively, showing a cooling of $1-1.3^{\circ} \mathrm{C}$. Both records agree that the coldest conditions occurred around $\sim 3.2 \mathrm{ka} \mathrm{BP}$ (Fig. 4), although a second SST minimum at $\sim 2.4 \mathrm{ka} B P$ evident in the diatom reconstruction is represented in the dinocyst-based reconstruction only by a subtle interruption of a general warming trend.

The diatom-based reconstruction shows warmer reconstructed temperatures than the dinocyst-based reconstruction and the modern measured summer SST (June-August) of $10.9^{\circ} \mathrm{C}$. The reconstructed temperatures are similar after $3 \mathrm{ka} B P$ but differ by as much as $2{ }^{\circ} \mathrm{C}$ before this. Given the diatom transfer function RMSEP of $1.1^{\circ} \mathrm{C}$ and the dinocyst RMSE of $1.7^{\circ} \mathrm{C}$ (Van Nieuwenhove et al., 2018) the difference may have been caused by this uncertainty. A further reason may be because the diatom transfer function reconstructs the peak summer warming (the strongest statistical relationship is between diatom assemblages and August temperature; Koç-Karpuz and Schrader, 1990; Berner et al., 2008), whereas the dinocyst transfer function used here reconstructs the average summer temperature from July-September (Van Nieuwenhove et al., 2018). Alternatively, there may be some differences in the water depths that diatoms and dinoflagellates occupy.

The overall long-term cooling trend in the diatom-based SST reconstruction for the last $6.1 \mathrm{ka}$ fits with the widely established cooling in the subpolar North Atlantic since the Holocene Thermal Maximum, resulting from decreasing Northern Hemisphere summer insolation (e.g. Calvo et al., 2002; Marchal et al., 2002; Andersen et al., 2004a, 2004b; Andersson et al., 2010; Jiang et al., 2015; Sejrup et al., 2016). Since 6.1 ka BP there was also a gradual increase in the Sub-Arctic assemblage (typical of the central and western north Atlantic including the SPG) and a gradual decrease in the North Atlantic assemblage (typical of the eastern North Atlantic and the NAC). Given the modern spatial distribution of these water masses (Fig. 1) this may support a south-eastward expansion of cooler water masses. The SST cooling registered between 4 and $2 \mathrm{ka}$ $\mathrm{BP}$ represents a remarkable deviation from the overall negative summer SST trend and therefore this interval will be the focus for discussion in the following sections. We first summarise the spatial pattern of SST in the subpolar North Atlantic and then discuss possible driving factors behind the observed variability at 4-2 ka BP.

\subsection{Oceanographic changes at 4-2 ka BP}

In the Iceland Basin (core Rapid 21-COM) and Reykjanes Ridge area (core LO09-14, Figs. 6G and 7 (point 6)) SST reconstructions based on diatoms and dinocysts show the cool event at 4-2 ka BP (Miettinen et al., 2012; Berner et al., 2008; Solignac et al., 2008), although an alkenone-based SST reconstruction (core MD95-2015) shows only minimal cooling at this time (Fig. 7 (point 9); Marchal et al., 2002). However, $\mathrm{Mg} / \mathrm{Ca}$ reconstructions from the Iceland Basin (MD99-2251 and RAPiD-12-1K), which reflect winter 


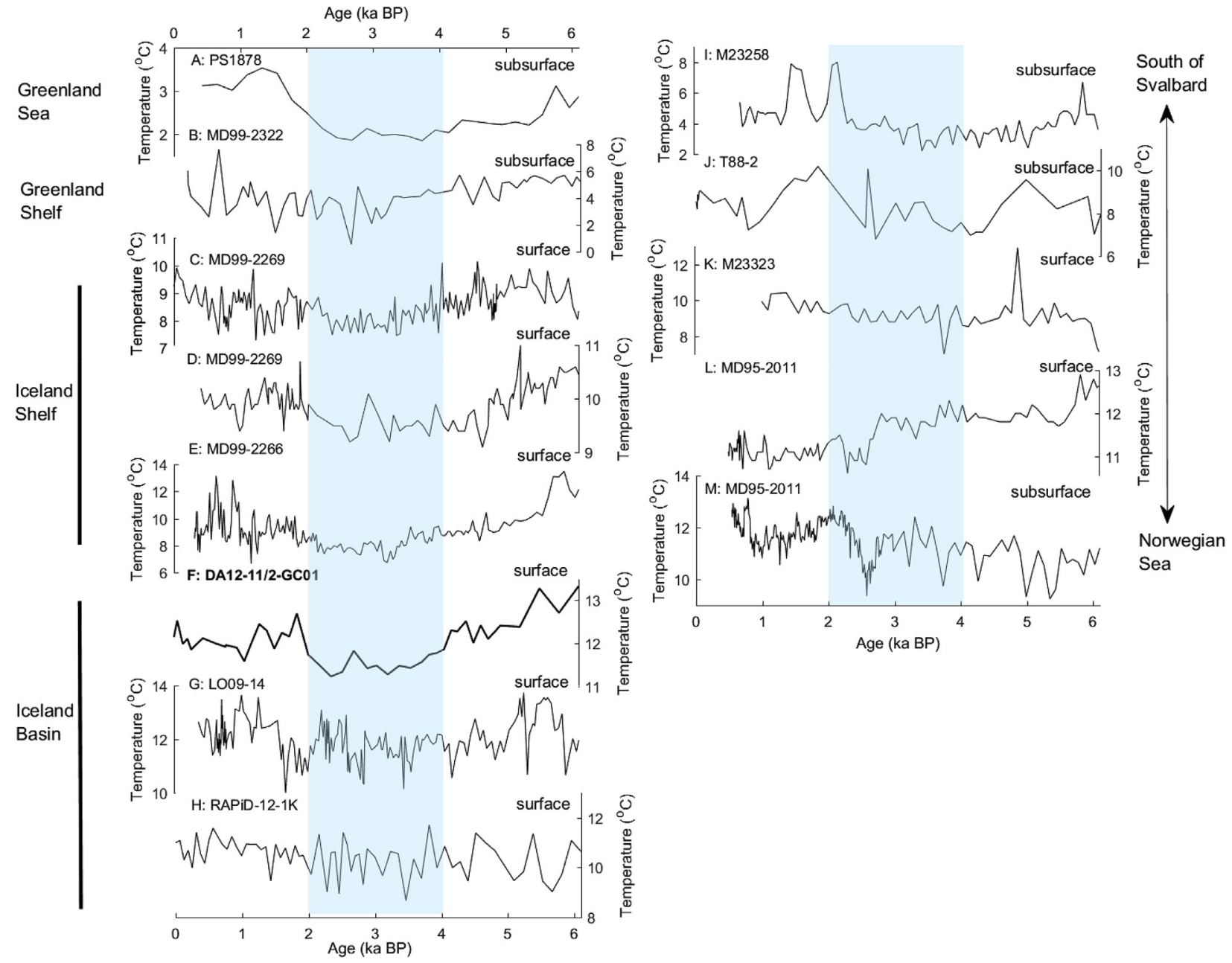

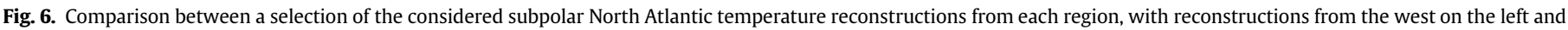

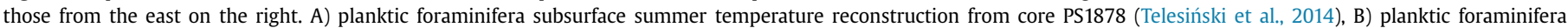

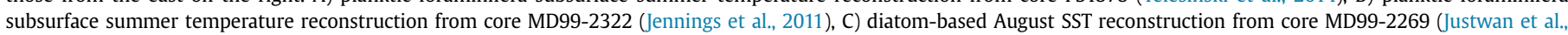

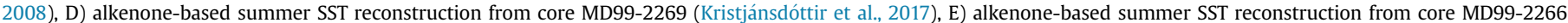

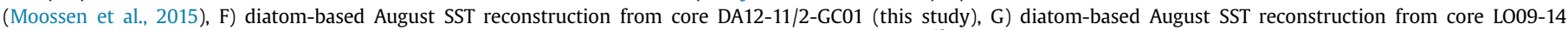

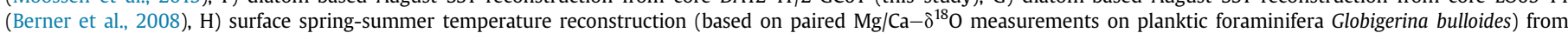

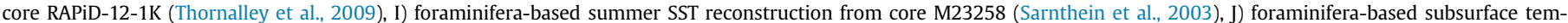

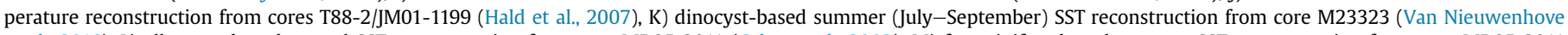

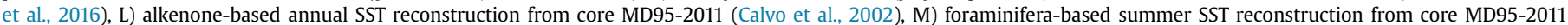
(Andersson et al., 2010). The shaded area highlights the reconstructed cold SST interval at c. 4-2 ka BP of this study.

temperature, show contrasting results: both greater variability at 4 2 ka BP (Thornalley et al., 2009; Figs. 6H and 7 (point 8)) which may reflect the cold event, and warming after 4 ka BP (Fig. 7 (points 7 and 8); Farmer et al., 2008). Sub-surface temperature reconstructions based on planktic foraminifera also do not have a clear cold event; instead they show two large oscillations after 4 ka BP (core ODP-984; Fig. 7 (point 5); Came et al., 2007), a strong warming at 4-2 ka BP (core MD95-2015; Marchal et al., 2002; Fig. 7 (point 9)) and relatively stable temperatures (NA8722; Fig. 7 (point 10); Duplessy et al., 1992). Therefore, between 4 and 2 ka BP this region had a summer cooling of the surface water, which does not appear to have influenced the subsurface.

On the northwest Iceland shelf (cores MD99-2269 and MD992266) the reconstructions of summer SST based on diatoms and alkenones show a cooler interval at 4-2 ka BP (Fig. 6C, D and 6E and 7 (point 1 \& 2); Andersen et al., 2004a; Justwan et al., 2008; Kristjánsdóttir et al., 2017). On the northeast Iceland shelf, however, diatom and alkenone-derived reconstructions (cores MD99-2275 and JR51-GC35) do not show this cooling; the different records instead display either a shorter but high magnitude cold event at 3.2-2.6 ka BP (Fig. 7 (point 3); Bendell and Rosell-Melé, 2007), a gradual cooling trend (Fig. 7 (point 4); Jiang et al., 2015) or warming (Fig. 7 (point 4); Sicre et al., 2008).

On the East Greenland shelf the occurrence of a cold interval at 4-2 ka BP is somewhat uncertain. It is shown by surface (diatombased) and subsurface (foraminifera-based) temperature reconstructions from core MD99-2322 with a cooling at c. 3.5-3 ka BP followed by a warming trend (Figs. 6B and 7 (point 11); Jennings et al., 2011; Miettinen et al., 2015), as well as in core Fox05R near Sermilik (Andresen et al., 2013), where inflow of warm Atlantic subsurface water reduced after $3.6 \mathrm{ka}$ BP. However, a diatom study of cores HU93030-19A and BS88-06-5A showed low temperatures after 2 ka BP without warming (Andersen et al., 2004a).

In the Greenland Sea, a foraminifera-based subsurface temperature reconstruction shows pronounced subsurface cooling at c.5.7-2 ka BP followed by warming (core PS1878; Figs. 6A and 7 


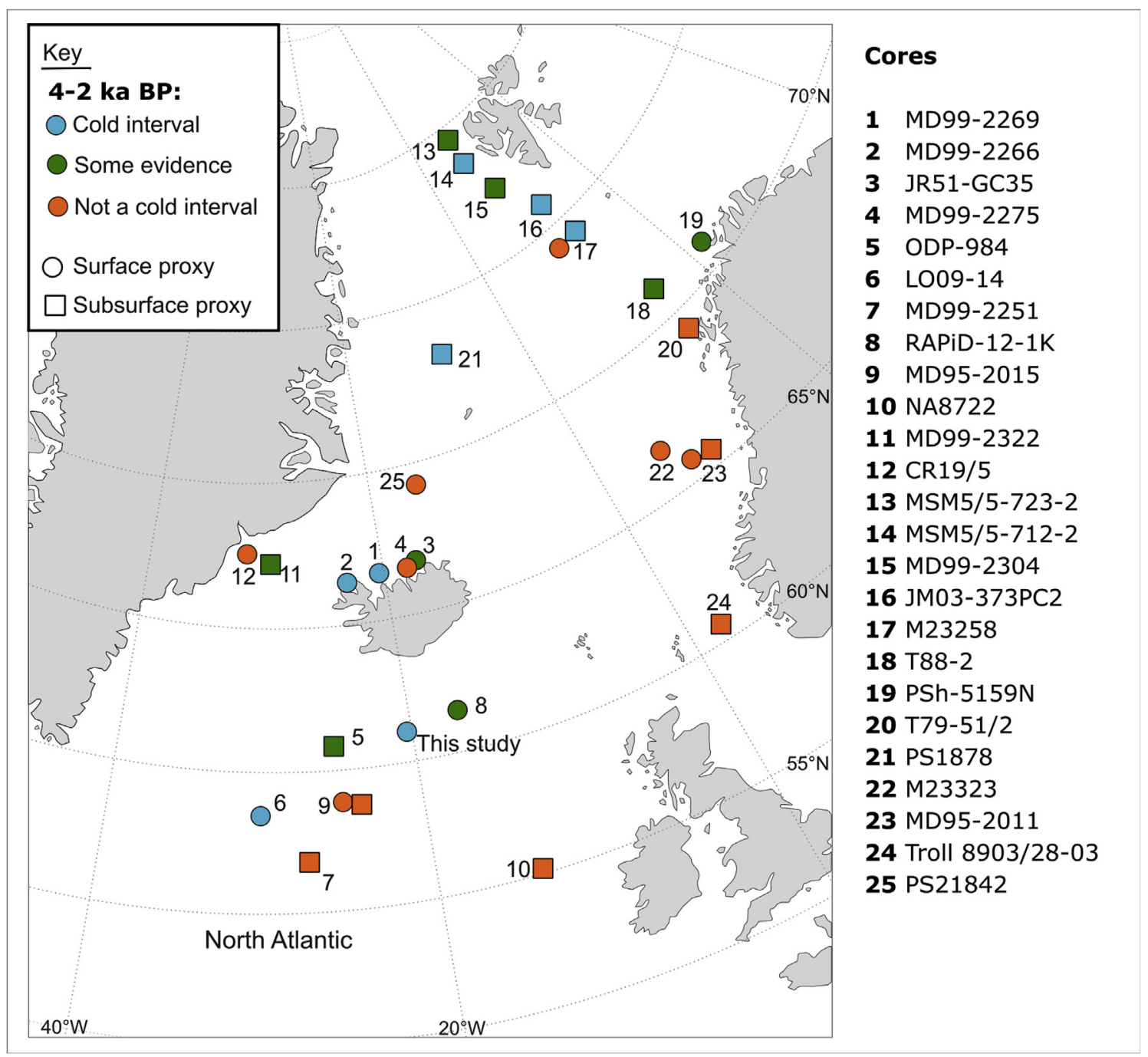

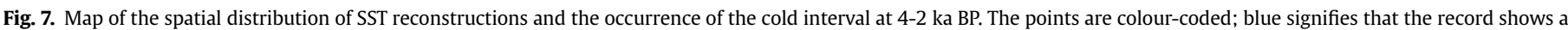

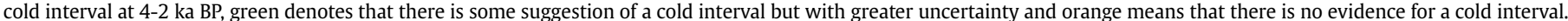

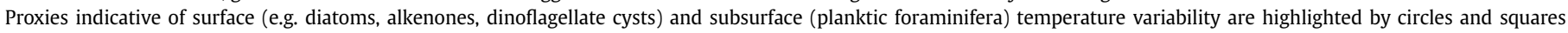

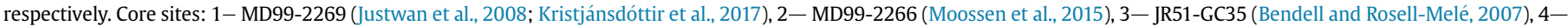

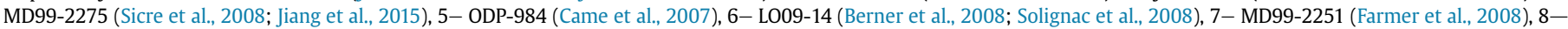

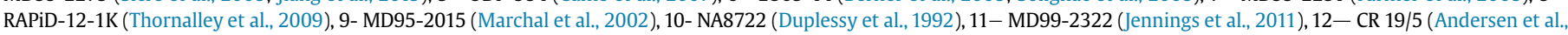

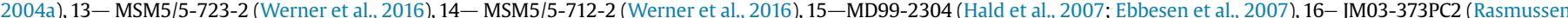

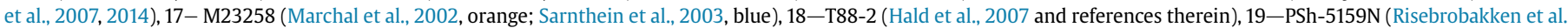

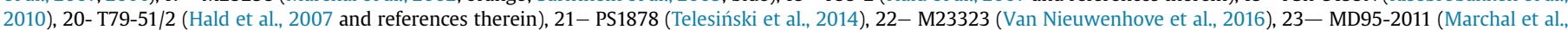

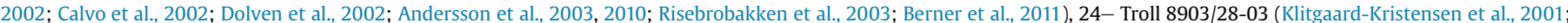

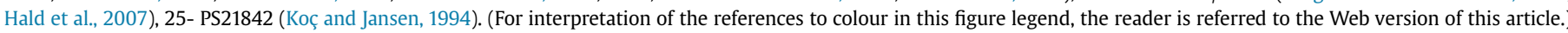

(point 21); Telesiński et al., 2014), however surface temperatures (diatom-based SST from core PS21842) appear to have decreased at 7-2 ka BP before they stabilised (Fig. 7 (point 25); Koç and Jansen, 1994). Further records from both the East Greenland Shelf and the Greenland-Iceland Seas would be required to identify with greater confidence the temperature patterns for these regions.

In the region to the west and south of Svalbard the majority of temperature reconstructions are based on foraminifera and therefore reflect subsurface temperatures. Many of these show the subsurface temperatures cooled between 5 and 3-2 ka BP, followed by warming (cores MSM5/5-723-2, MSM5/5-712-2, MD99-2304, JM03-373PC2; Figs. $6 \mathrm{I}$ and Fig. 7 (points 13, 14, 15, 16, 17); Sarnthein et al., 2003; Ebbesen et al., 2007; Rasmussen et al., 2007, 2014; Werner et al., 2013, 2016). A transect of cores between Norway and Svalbard (including core T88-2; Figs. 6J and 7 (point 18)) shows that the 3 northernmost records (north of $70^{\circ}$ ) had cooler subsurface temperatures at 5-3 ka BP (Hald et al., 2007). However, an alkenone-based SST record (core M23258) instead indicates a cooling after 3 ka BP (Fig. 7 (point 17), Marchal et al., 2002). Therefore, in this region it is clear that the subsurface signal is in line with the DA12-11/2-GC01 core reconstruction, however the SST patterns remain unclear.

Within the Norwegian Sea reconstructions do not show a cold event at 4-2 ka BP. Offshore northern Norway, an alkenone SST reconstruction (PSh-5159N) showed cooling after $3 \mathrm{ka}$ BP that lasted until present (Fig. 7 (point 19); Risebrobakken et al., 2010). However, IRD here increased between c. 5-2 ka BP, which is interpreted as representing cooler summers when sea ice could reach the site (Risebrobakken et al., 2010). On the Vøring plateau there are some contrasting patterns: alkenone and diatom-based SST estimates 
from core MD95-2011 (Fig. 7 (point 23)) indicate a cooling trend at 4.0-2.5 ka BP followed by stable temperatures (Fig. 6L; Marchal et al., 2002; Calvo et al., 2002; Birks and Koç, 2002; Berner et al., 2011), a radiolarian-based reconstruction shows no changes (Dolven et al., 2002) and a warming trend is shown by a dinocystbased SST reconstruction (core M23323; Figs. 6K and 7 (point 22); Van Nieuwenhove et al., 2016). Subsurface (foraminifera-based) temperature reconstructions also do not show a cold event, instead showing only little variation (Core Troll 8903; Fig. 7 (point 24); Klitgaard-Kristensen et al., 2001; Hald et al., 2007) or a warming trend (MD95-2011, Fig. 6M; Risebrobakken et al., 2003; Andersson et al., 2003, 2010). Therefore, it can be concluded that a pronounced cold period did not occur at 4-2 ka BP in the Norwegian Sea.

In summary, the period between 4 and 2 ka BP that featured colder summer SSTs in the Iceland Basin is manifested in some, but not all, surface and subsurface temperature reconstructions south and north of Iceland, from the East Greenland Shelf, the Greenland Sea and to the south and west of Svalbard (Fig. 7). The identification of this cold event across a range of sites supports that this was not a result of local factors, such as glacier fluctuations, or methodological factors, such as the long-distance transport of diatoms. In some of the reconstructions (such as LO09-14 and MD99-2269 from the Iceland Basin and shelf, PS1878 from the Greenland Sea and T88-1 and M23258 south of Svalbard; Fig. 6) the cool period began earlier at c. 5 ka BP. Some of the difference may be explained by age uncertainties from dating and marine reservoir ages. However, between 5 and 4 ka BP the DA12-11 core and others show gradual cooling, supporting that the onset of this cool event began around 5 ka BP. It is notable that the cold interval is not captured in reconstructions that are situated along the Norwegian coast but is primarily identified in reconstructions from the sites directly influenced by the EGC, or in regions proximal to this current. Principal component analysis on surface and near-surface temperature reconstructions from the subpolar north AtlanticFennoscandian region by Sejrup et al. (2016) shows cold surface temperatures during the Late Holocene. The subsurface temperature reconstructions however suggest a cooling centred at c. 2 ka BP in the west followed by warming, with opposite patterns towards Norway (Sejrup et al., 2016). Although there is some difference in the timing of the cooling event, the contrasting patterns between the east and west, and the spatial distribution of the subsurface temperature, reflects the findings discussed here.

\subsection{Potential causes of the cold period at 4-2 ka BP}

\subsubsection{Arctic water outflow}

The cold interval at 4-2 ka BP coincides with a period that had prevalent negative NAO conditions (Olsen et al., 2012, Fig. 8C) and southward-shifted storm-tracks (Bakke et al., 2008; Orme et al., 2017, Fig. 8A and B), supporting the possibility that atmospheric forcing caused the observed SST patterns. The SST decrease and the increase in the Sub-Arctic assemblage at 4-2 ka BP, may have been caused by a greater southward transport of polar water by the EGC in response to a period with persistent negative NAO. Such phenomena were observed at sub-decadal scale in the 20th century when strongly negative NAO anomalies and high pressure over Greenland caused strengthened northerly winds over east Greenland, a strengthened EGC and increased polar water transport from the Arctic Ocean (e.g. the Great Salinity Anomaly of the 1960's; Blindheim et al., 2000). Given the complex forcings and feedbacks between atmospheric and ocean temperatures and ocean circulation, it is conceivable that ocean surface water cooling may have been the cause (rather than the result) of the generally negative NAO at 4-2 ka BP. However, we consider this unlikely as the SST cooling appears to be regional (Fig. 7) and goes against the general trend of gradual cooling and increasing sea ice in the Arctic (Kim et al., 2004; Vare et al., 2009) that most likely would have had a greater influence on the atmosphere. Thus, the surface water cooling was more likely a result of a generally negative NAO scenario. Modelling studies have shown similar events at multidecadal timescales; these feature an export of fresh, cold water and sea ice from the Arctic into the Greenland Sea, which was then transported south through the Denmark Strait into the North Atlantic (including the Icelandic Basin) as a result of strengthened northerly winds (Delworth et al., 1997; Renssen et al., 2005). Interestingly, the Renssen et al. (2005) simulation indicates that these episodes occurred particularly in the period 3.5-1.5 ka BP. Therefore, we speculate that the period 4-2 ka BP had enhanced southward transport of the EGC, which allowed subarctic water into the Iceland Basin, either directly from the Denmark Strait and across the Reykjanes Ridge with a south-eastward shift in the subarctic front, or via recirculation within the SPG.

Various studies have found evidence that the EGC was stronger at this time. On the East Greenland shelf, a stronger EGC at 4.5-1.4 ka BP has been inferred from variations in sea ice (Perner et al., 2015; Kolling et al., 2017) and after $3.6 \mathrm{ka}$ BP foraminiferal changes indicate an increased influence of polar water, although this continued after 2 ka BP (Andresen et al., 2012). To the north, Justwan et al. (2008) interpreted cooler SSTs and an increase in an Arctic diatom assemblage as reflecting a strengthened East Iceland Current at 4.7-2.2 ka BP. In addition, to the west of Svalbard, cold temperatures and enhanced sea ice at 5.2 to $3 \mathrm{ka}$ BP have been interpreted as a spread of Arctic water through the Fram Strait along a strengthened EGC (Werner et al., 2013). Finally, a study of the temporal variability of reservoir ages during the Late Holocene from the north of Iceland shows higher reservoir ages at 4/3 - 2 ka $\mathrm{BP}$ in three cores, which is interpreted as resulting from greater input of 'old' carbon from the Arctic Ocean via a strengthened EGC (Eiriksson et al., 2004). The strengthened EGC may have allowed more Arctic water to enter the Iceland Basin at around $4 \mathrm{ka} \mathrm{BP}$, as evidenced by dinoflagellate cyst variability (Solignac et al., 2004; Van Nieuwenhove et al., 2018) and fluctuations in foraminifera and diatoms on the Reykjanes Ridge at 3-2 ka BP (Rasmussen et al., 2002). Together, the evidence supports that the period 5/4 ka BP until 2 ka BP may have had greater atmospherically-driven Arctic water outflow along the EGC.

\subsubsection{Greenland ice melt}

A second hypothesis to explain the cooling at 4-2 ka BP is that of increased meltwater runoff from Greenland. Modern measurements show a strong negative correlation between the NAO and Greenland temperature (Serreze et al., 1997; Chylek et al., 2004); therefore, the negative NAO at 4-2 ka BP (Olsen et al., 2012; Faust et al., 2016) may have caused anomalous regional warming and increased the amount of meltwater entering the North Atlantic and Greenland Sea. This is supported by evidence of warmer temperatures over the Greenland ice sheet between 4 and 2 ka BP (Alley, 2004; Briner et al., 2016) but contradicted by other reconstructions that show cooling trends or stable temperatures over Greenland during this interval (e.g. Johnsen et al., 2001; Kobashi et al., 2017). During the mid-late Holocene, the period before c.2-3 ka BP had a steep reduction in elevation at the GRIP drill site, before the elevation slightly increased after 2 ka BP (Vinther et al., 2009), and the Greenland ice sheet reached its minimum extent at 5-3 ka BP (Briner et al., 2016). This latter study in particular supports that ice loss from Greenland may be a possible factor for explaining the cooling of the subpolar North Atlantic. An input of meltwater is supported by evidence of lower salinities south of Iceland, on the Greenland Rise and the Rockall Plateau at c. 5-2 ka BP (Duplessy et al., 1992; Solignac et al., 2004; Came et al., 2007; 


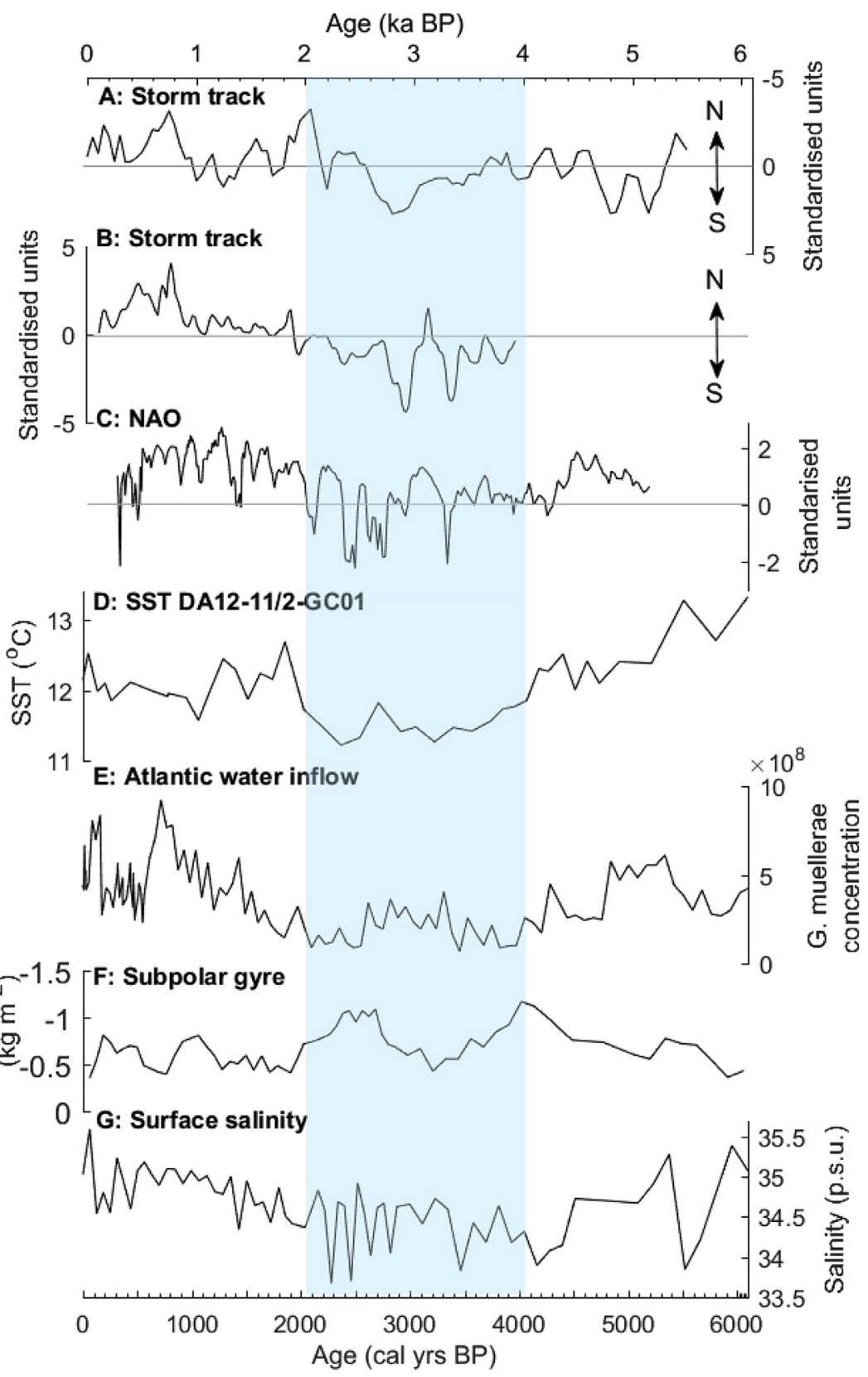

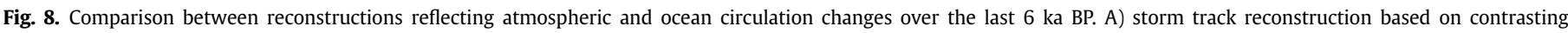

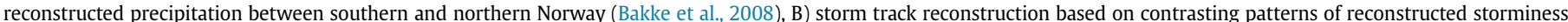

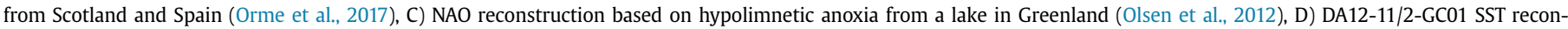

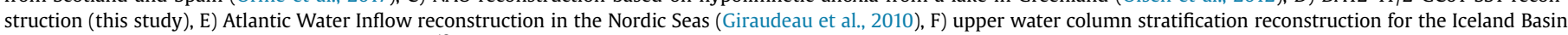

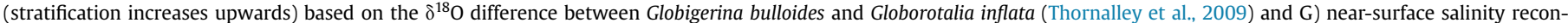

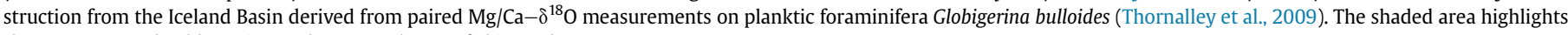
the reconstructed cold SST interval at c. 4-2 ka BP of this study.

Thornalley et al., 2009; Van Nieuwenhove et al., 2018). In the Iceland Basin (RAPiD-12-1K) the negative NAO events in particular coincide with low salinity anomalies in the surface waters (Thornalley et al., 2009, Fig. 8G). However, this freshening may have equally been caused by a strengthened EGC and greater export of freshwater from the Arctic.

A model forced by the Early Holocene melting of the Greenland Ice Sheet showed the clearest SST response around southeastern Greenland, extending into the Iceland Basin and through the Denmark Strait (Blaschek and Renssen, 2013). This study finds that close to Greenland the freshening of surface water caused stratification and cooling because of reduced vertical mixing, while cooling across the North Atlantic was the result of reduced AMOC strength following meltwater input to the Labrador Sea (Blaschek and Renssen, 2013). To know if similar changes occurred at 4-2 ka $\mathrm{BP}$, we require estimates of the volume of meltwater produced during the period of reduced Greenland ice sheet extent at 5-2 ka BP (Briner et al., 2016) and modelling of the effects of smaller freshwater inputs. However, convection in this region is very sensitive to even small quantities of additional freshwater because of strong amplifying feedbacks related to the circulation of the subpolar gyre (Born et al., 2010; Born and Stocker, 2014). 


\subsubsection{Northward heat transport and the effects of SPG dynamics}

The dynamics of the SPG and associated modulation of the northward heat transport is another potential cause of the observed cooling at 4-2 ka BP. The increase of the sub-Arctic assemblage at 4-2 ka BP may support this, as in addition to being found to the north of Iceland it is also an assemblage characteristic of the SPG. The influence of the NAO on the SPG is uncertain. It has been suggested that during the 1990's the positive to negative shift in the NAO caused the SPG to change from an E-W to a N-S configuration, which resulted in warmer waters being transported to the Iceland Basin (Hátún et al., 2005). However, subsequent analysis would suggest that such longitudinal shifts of the eastern SPG do not control the properties of the eastern subpolar North Atlantic, and that the NAO does not cause changes in the configuration of the SPG (Foukal and Lozier, 2017). Meanwhile, a model suggests that a weaker SPG during negative NAO periods (with a blocking high pressure centred over the British Isles and eastern North Atlantic) instead causes cooling in the Iceland Basin due to reduced advection (Moffa-Sanchez et al., 2014).

Reconstructions of SPG dynamics and northward heat transport show steady or oscillating conditions rather than a clear change at 4-2 ka BP (Fig. 8F; Thornalley et al., 2009; Repschläger et al., 2017; Tegzes et al., 2017). Furthermore, in core DA12-11/2-GC01 the dinocyst Operculodinium centrocarpum, a species often found within waters from the NAC, shows high values since $6.8 \mathrm{ka}$ BP and particularly at c. $4.4 \mathrm{ka} \mathrm{BP}$, followed by declining values to present (Van Nieuwenhove et al., 2018), likely reflecting a continuous reduction in the northward heat transport. This evidence suggests that at this time the SPG and NAC were not influenced by the negative NAO and did not cause the SST cooling. The lack of evidence for a cold interval along the Norwegian coast (Fig. 7) may also support that NAC heat transport was not reduced, although this region may not be sensitive to NAO changes if it was influenced by NAC water during both positive and negative NAO phases (Blindheim et al., 2000). On the other hand, a record of Atlantic Water inflow to the Nordic Seas does show a strong similarity with the NAO and SST reconstructions, with reduced strength during the period 4-2 ka BP (Giraudeau et al., 2010, Fig. 8 E), which might indicate that heat transport to the Iceland Basin was also reduced at this time if the NAC weakened. In any case, the ambiguity in the different proxy reconstructions outlined above precludes concluding firmly that the millennial SST variations were caused by atmospherically-driven changes in SPG strength and northward heat transport.

In summary, we consider that the SST cooling at 4-2 ka BP may have been caused by either enhanced Arctic outflow via the EGC (section 5.3.1) or enhanced ice melt from East Greenland (section 5.3.2), both of which may be associated with negative NAO circulation. The currently available evidence of northward heat transport and SPG dynamics (section 5.3.3.) does not strongly support that reduced heat transport caused the observed cooling.

\subsection{Wider ocean changes}

Lower salinity and colder water entering the subpolar north Atlantic (resulting from either Arctic outflow or melting of the Greenland ice sheet) may have influenced the wider ocean circulation, including the rates of deep water formation (i.e. Denmark Strait Overflow Water (DSOW) and North Atlantic Deep Water) and as such the vigour of the AMOC. Observations indicate that during the strongly negative NAO of the 1960's there was increased deepwater formation in the Greenland Sea due to stronger northerly winds, strong cooling and increased sea ice formation (which led to brine production) (Dickson et al., 1996). Therefore enhanced deepwater formation at 7-3 ka BP in the Greenland Sea (shown by high $\delta^{13} \mathrm{C}$ values; Telesiński et al., 2014) may have resulted from this direct atmospheric forcing. Furthermore, since DSOW is formed by water transported southwards by the EGC (Mauritzen, 1996), the strengthened outflow of DSOW at 6.5-3 ka BP southwest of Greenland (MD99-2227) (Fagel et al., 2004) may have been the result of the strengthened EGC. Increased freshwater input may also have caused a strengthening of the Labrador Current at 5-3.1 ka BP, as it is known that varying input can modulate its vigour (Rashid et al., 2017). While Rashid et al. (2017) did not identify a freshwater input that could account for the high Labrador Current strength, we suggest that it may have been supplied by a NAOdriven strengthening of the EGC or melting from Greenland. This evidence supports that ocean circulation beyond the northwest Atlantic could have been influenced by the negative NAO circulation at 4-2 ka BP.

\section{Conclusions}

A diatom-based SST reconstruction from core DA12-11/2-GC01, retrieved from the Iceland Basin, shows a pronounced SST cooling between 4 and $2 \mathrm{ka} \mathrm{BP}$, with warmer temperatures prior to $4 \mathrm{ka} \mathrm{BP}$ and after 2 ka BP. Comparison of the new reconstruction with others from the subpolar North Atlantic indicates that this cold period was also observed in some reconstructions to the west of the study region, in particular from locations under the influence of the East Greenland Current.

We propose three hypotheses that might explain the observed cooling and its spatial pattern. The first, and perhaps most likely cause of the cooling, is that a persistently negative NAO at this time caused strengthening of northerly winds east of Greenland, which strengthened the EGC, bringing cool Arctic water as far south as the Icelandic Basin. Alternatively, a greater input of meltwater from Greenland caused by negative NAO-induced atmospheric warming may have caused the SST cooling and freshening during this period. A third hypothesis stipulates that the cooling was caused by reduced northward heat transport via the NAC or SPG but this is not supported by much of the available evidence. Although presented here separately, we consider it likely that the three mechanisms may have been operating concurrently.

It is predicted that negative NAO-like circulation may characterise future climate (e.g. Seierstad and Bader, 2009; Vihma, 2014) and our results indicate that this may result in cooling in the western region of the subpolar North Atlantic. At 4-2 ka BP this appears to have caused strengthened Greenland Sea deepwater formation and DSOW (Fagel et al., 2004; Telesiński et al., 2014), and a similar response may be expected with future climate change. This may in turn influence the AMOC strength, but further research would be required to confirm this for the period 4-2 ka BP and to apply this feedback to future climate scenarios.

\section{Declarations of interest}

None.

\section{Acknowledgements}

We would like to thank the captain, crew and scientific party of the DA12-11/2 expedition onboard R/V Dana for their work and efforts in recovering the core. The research cruise was funded by the Danish Centre for Marine Sciences (2016-03/DCH) (Dansk Center for Havforskning) as part of a PhD course "Benthic Research at Sea" taking place in September 24-30, 2012. LO, AM, DD, KH, AB and RM acknowledge funding from the Research Council of Norway (grant no. 248776/E10) and Ministry of Earth Science, Earth System Science Organization (MoES/Indo-Nor/PS-2/2015). Additional 
funding was obtained from the Independent Research Fund Denmark/Natural Science (G-Ice project no 7014-00113B; grant to MSS) and the Aarhus University Research Foundation (AUFF, grant to $\mathrm{CP}$ ). Many thanks to the helpful comments from two anonymous reviewers. Additional thanks to Svetlana Divina for preparation of the diatom slides.

\section{References}

Aagaard, K., Carmack, E.C., 1989. The role of sea ice and other fresh water in the Arctic circulation. J. Geophys. Res. Oceans 94, 14485-14498.

Aagaard, K., Coachman, L.K., 1968. The East Greenland current north of Denmark strait: Part I. Arctic 181-200.

Aagaard, K., Greisman, P., 1975. Toward new mass and heat budgets for the Arctic Ocean. J. Geophys. Res. 80, 3821-3827.

Abrantes, F. Lebreiro, S., Rodrigues, T., Gil, I., Bartels-Jónsdóttir, H., Oliveira, P., Kissel, C., Grimalt, J., 2005. Shallow-marine sediment cores record climate variability and earthquake activity off Lisbon (Portugal) for the last 2000 years. Quat. Sci. Rev. 24, 2477-2494.

Alley, R.B., 2004. GISP2 ice core temperature and accumulation data, IGBP PAGES/ World data center for paleoclimatology. In: Data Contribution Series \#2004013. NOAA/NGDC Paleoclimatology Program, Boulder CO, USA.

Andersen, C., Koc, N., Jennings, A., Andrews, J., 2004a. Nonuniform response of the major surface currents in the Nordic Seas to insolation forcing: implications for the Holocene climate variability. Paleoceanography 19.

Andersen, C., Koc, N., Moros, M., 2004b. A highly unstable Holocene climate in the subpolar North Atlantic: evidence from diatoms. Quat. Sci. Rev. 23, 2155-2166.

Andersson, C., Pausata, F.S., Jansen, E., Risebrobakken, B., Telford, R.J., 2010. Holocene trends in the foraminifer record from the Norwegian Sea and the north Atlantic Ocean. Clim. Past 6, 179-193.

Andersson, C., Risebrobakken, B., Jansen, E., Dahl, S.O., 2003. Late Holocene surface ocean conditions of the Norwegian sea (Vøring plateau). Paleoceanography 18, 1044.

Andresen, C., Hansen, M., Seidenkrantz, M.-S., Jennings, A., Knudsen, M., NørgaardPedersen, N., Larsen, N., Kuijpers, A., Pearce, C., 2012. Mid-to late-Holocene oceanographic variability on the Southeast Greenland shelf. Holocene 23, 167-178.

Andresen, C., Hansen, M., Seidenkrantz, M.-S., Jennings, A., Knudsen, M., NørgaardPedersen, N., Larsen, N., Kuijpers, A., Pearce, C., 2013. Mid-to late-Holocene oceanographic variability on the Southeast Greenland shelf. Holocene 23, 167-178.

Bakke, J., Lie, Ø., Dahl, S.O., Nesje, A., Bjune, A.E., 2008. Strength and spatial patterns of the Holocene wintertime westerlies in the NE Atlantic region. Global Planet. Change 60, 28-41.

Belkin, I.M., Levitus, S., Antonov, J., Malmberg, S.-A., 1998. "Great salinity anomalies" in the north Atlantic. Prog. Oceanogr. 41, 1-68.

Bellucci, A., Gualdi, S., Scoccimarro, E., Navarra, A., 2008. NAO-ocean circulation interactions in a coupled general circulation model. Clim. Dynam. 31, 759-777.

Bendle, J.A., Rosell-Melé, A., 2007. High-resolution alkenone sea surface temperature variability on the North Icelandic Shelf: implications for Nordic Seas palaeoclimatic development during the Holocene. Holocene 17, 9-24.

Berner, K., Koç, N., Divine, D., Godtliebsen, F., Moros, M., 2008. A decadal-scale Holocene sea surface temperature record from the subpolar North Atlantic constructed using diatoms and statistics and its relation to other climate parameters. Paleoceanography 23.

Berner, K., Koç, N., Godtliebsen, F., Divine, D., 2011. Holocene climate variability of the Norwegian Atlantic Current during high and low solar insolation forcing. Paleoceanography 26.

Bianchi, G., McCave, I., 2000. Hydrography and sedimentation under the deep western boundary current on Björn and Gardar Drifts, Iceland Basin. Mar. Geol. $165,137-169$

Birks, H., 1998. Numerical tools in palaeolimnology-progress, potentialities, and problems. J. Paleolimnol. 20, 307-332.

Birks, C.J., Koç, N., 2002. A high-resolution diatom record of late-Quaternary seasurface temperatures and oceanographic conditions from the eastern Norwegian Sea. Boreas 31, 323-344.

Blaschek, M., Renssen, H., 2013. The Holocene thermal maximum in the Nordic Seas: the impact of Greenland Ice Sheet melt and other forcings in a coupled atmosphere-sea-ice-ocean model. Clim. Past 9, 1629.

Blindheim, J., Borovkov, V., Hansen, B., Malmberg, S.-A., Turrell, W., Østerhus, S., 2000. Upper layer cooling and freshening in the Norwegian Sea in relation to atmospheric forcing. Deep Sea Res. Oceanogr. Res. Pap. 47, 655-680.

Born, A., Nisancioglu, K.H., Braconnot, P., 2010. Sea ice induced changes in ocean circulation during the Eemian. Clim. Dynam. 35, 1361-1371.

Born, A., Stocker, T.F., 2014. Two stable equilibria of the Atlantic subpolar gyre. J. Phys. Oceanogr. 44, 246-264.

Briner, J.P., McKay, N.P., Axford, Y., Bennike, O., Bradley, R.S., de Vernal, A., Fisher, D., Francus, P., Fréchette, B., Gajewski, K., 2016. Holocene climate change in Arctic Canada and Greenland. Quat. Sci. Rev. 147, 340-364.

Bronk Ramsey, C., 2009. Bayesian analysis of radiocarbon dates. Radiocarbon 51, $337-360$.

Calvo, E., Grimalt, J., Jansen, E., 2002. High resolution U37K sea surface temperature reconstruction in the Norwegian Sea during the Holocene. Quat. Sci. Rev. 21, 1385-1394.

Came, R.E., Oppo, D.W., McManus, J.F., 2007. Amplitude and timing of temperature and salinity variability in the subpolar North Atlantic over the past $10 \mathrm{ky}$. Geology 35, 315-318.

Chylek, P., Box, J.E., Lesins, G., 2004. Global warming and the Greenland ice sheet. Climatic Change 63, 201-221.

Collins, M., Knutti, R., Arblaster, J., Dufresne, J.-L., Fichefet, T., Friedlingstein, P., Gao, X., Gutowski, W., Johns, T., Krinner, G., 2013. Long-term climate change: projections, commitments and irreversibility. In: IPCC (Ed.), Climate Change 2013: the Physical Science Basis. Cambridge University Press, Cambridge. IPCC Working Group I Contribution to AR5.

Curry, R.G., McCartney, M.S., 2001. Ocean gyre circulation changes associated with the North Atlantic Oscillation. J. Phys. Oceanogr. 31, 3374-3400.

De Boisseson, E., Thierry, V., Mercier, H., Caniaux, G., 2010. Mixed layer heat budget in the Iceland Basin from Argo. J. Geophys. Res. Oceans 115.

De Boisséson, E., Thierry, V., Mercier, H., Caniaux, G., Desbruyères, D., 2012. Origin formation and variability of the subpolar mode water located over the Rey kjanes Ridge. J. Geophys. Res. Oceans 117.

Delworth, T.L., Manabe, S., Stouffer, R.J., 1997. Multidecadal climate variability in the Greenland Sea and surrounding regions: a coupled model simulation. Geophys. Res. Lett. 24, 257-260.

Dickson, R., Lazier, J., Meincke, J., Rhines, P., Swift, J., 1996. Long-term coordinated changes in the convective activity of the North Atlantic. Prog. Oceanogr. 38, $241-295$.

Dolven, J.K., Cortese, G., Bjørklund, K.R., 2002. A high-resolution radiolarian-derived paleotemperature record for the Late Pleistocene-Holocene in the Norwegian Sea. Paleoceanography 17

Duplessy, J.-C., Labeyrie, L., Arnold, M., Paterne, M., Duprat, J., van Weering, T.C., 1992. Changes in surface salinity of the North Atlantic Ocean during the last deglaciation. Nat 358, 485.

Ebbesen, H., Hald, M., Eplet, T.H., 2007. Lateglacial and early Holocene climatic oscillations on the western Svalbard margin, European Arctic. Quat. Sci. Rev. 26, 1999-2011.

Eden, C., Jung, T., 2001. north Atlantic interdecadal variability: oceanic response to the north Atlantic oscillation (1865-1997). J. Clim. 14, 676-691.

Eiríksson, J., Larsen, G., Knudsen, K.L., Heinemeier, J., Símonarson, L.A., 2004. Marine reservoir age variability and water mass distribution in the Iceland Sea. Quat. Sci. Rev. 23, 2247-2268.

Fagel, N., Hillaire-Marcel, C., Humblet, M., Brasseur, R., Weis, D., Stevenson, R., 2004 $\mathrm{Nd}$ and $\mathrm{Pb}$ isotope signatures of the clay-size fraction of Labrador Sea sediments during the Holocene: implications for the inception of the modern deep circulation pattern. Paleoceanography 19.

Farmer, E.J., Chapman, M.R. Andrews, J.E., 2008. Centennial-scale Holocene north Atlantic surface temperatures from $\mathrm{Mg} / \mathrm{Ca}$ ratios in Globigerina bulloides. Geochem. Geophys. Geosyst 9.

Faust, J.C., Fabiana, K., Milzer, G., Giraudeau, J., Knies, J., 2016. Past changes in the North Atlantic storm track driven by insolation and sea-ice forcing. Geology 45, 335-338.

Fettweis, X., Hanna, E., Lang, C., Belleflamme, A., Erpicum, M., Gallée, H., 2013. Brie communication" Important role of the mid-tropospheric atmospheric circulation in the recent surface melt increase over the Greenland ice sheet". Cryosphere 7, 241.

Folland, C.K., Knight, J., Linderholm, H.W., Fereday, D., Ineson, S., Hurrell, J.W., 2009 The summer North Atlantic Oscillation: past, present, and future. J. Clim. 22, $1082-1103$.

Foukal, N.P., Lozier, M.S., 2017. Assessing variability in the size and strength of the North Atlantic subpolar gyre. J. Geophys. Res. Oceans 122, 6295-6308.

Francis, J.A., Vavrus, S.J., 2012. Evidence linking Arctic amplification to extreme weather in mid-latitudes. Geophys. Res. Lett. 39.

Fratantoni, D.M., 2001. North Atlantic surface circulation during the 1990's observed with satellite-tracked drifters. J. Geophys. Res. Oceans 106, 22067-22093.

Giraudeau, J., Grelaud, M., Solignac, S., Andrews, J., Moros, M., Jansen, E., 2010. Millennial-scale variability in Atlantic water advection to the Nordic Seas derived from Holocene coccolith concentration records. Quat. Sci. Rev. 29, $1276-1287$.

Häkkinen, S., Rhines, P.B., 2004. Decline of subpolar north Atlantic circulation during the 1990s. Sciences 304, 555-559.

Hald, M., Andersson, C., Ebbesen, H., Jansen, E., Klitgaard-Kristensen, D., Risebrobakken, B., Salomonsen, G.R., Sarnthein, M., Sejrup, H.P., Telford, R.J., 2007. Variations in temperature and extent of Atlantic water in the northern north Atlantic during the Holocene. Quat. Sci. Rev. 26, 3423-3440.

Hátún, H., Sandø, A.B., Drange, H., Hansen, B., Valdimarsson, H., 2005. Influence of the Atlantic subpolar gyre on the thermohaline circulation. Sciences 309, 1841-1844.

Hurrell, J.W. Van Loon, H., 1997. Decadal Variations in Climate Associated with the North Atlantic Oscillation, Climatic Change at High Elevation Sites. Springer, pp. 69-94.

Imbrie, J., Kipp, N.G., 1971. Late Cenozoic Glacial Ages. Yale University Press.

Ionita, M., Scholz, P., Lohmann, G., Dima, M., Prange, M., 2016. Linkages between atmospheric blocking, Sea Ice export through Fram Strait and the Atlantic meridional overturning circulation. Sci. Rep. 6, 32881.

Jakobsen, P.K., Ribergaard, M.H., Quadfasel, D., Schmith, T., Hughes, C.W., 2003. Near-surface circulation in the northern North Atlantic as inferred from Lagrangian drifters: variability from the mesoscale to interannual. J. Geophys. 
Res. Oceans 108.

Jeansson, E., Jutterström, S., Rudels, B., Anderson, L.G., Olsson, K.A., Jones, E.P. Smethie Jr., W.M., Swift, J.H., 2008. Sources to the east Greenland current and its contribution to the Denmark Strait Overflow. Prog. Oceanogr. 78, 12-28.

Jennings, A., Andrews, J., Wilson, L., 2011. Holocene environmental evolution of the SE Greenland shelf north and south of the Denmark strait: irminger and east Greenland current interactions. Quat. Sci. Rev. 30, 980-998.

Jiang, H., Muscheler, R., Björck, S., Seidenkrantz, M.-S., Olsen, J., Sha, L., Sjolte, J., Eiríksson, J., Ran, L., Knudsen, K.-L., 2015. Solar forcing of Holocene summer seasurface temperatures in the northern North Atlantic. Geology 43, 203-206.

Johnsen, S.J., Dahl-Jensen, D., Gundestrup, N., Steffensen, J.P., Clausen, H.B., Miller, H., Masson-Delmotte, V., Sveinbjörnsdottir, A.E., White, J., 2001. Oxygen sotope and palaeotemperature records from six Greenland ice-core stations: camp Century, Dye-3, GRIP, GISP2, Renland and NorthGRIP. J. Quat. Sci. 16, 299-307.

Justwan, A., Koc, N., Jennings, A.E., 2008. Evolution of the Irminger and East Icelandic Current systems through the Holocene, revealed by diatom-based sea surface temperature reconstructions. Quat. Sci. Rev. 27, 1571-1582.

Kim, B.-M., Son, S.-W., Min, S.-K., Jeong, J.-H., Kim, S.-J., Zhang, X., Shim, T., Yoon, J.H. 2014. Weakening of the stratospheric polar vortex by Arctic sea-ice loss. Nat. Commun. 5, 4646 .

Kim, J.-H., Rimbu, N., Lorenz, S.J., Lohmann, G., Nam, S.-I., Schouten, S. Rühlemann, C., Schneider, R.R., 2004. North pacific and north Atlantic seasurface temperature variability during the Holocene. Quat. Sci. Rev. 23, 2141-2154.

Kissel, C., Van Toer, A., Laj, C., Cortijo, E., Michel, E., 2013. Variations in the strength of the north Atlantic bottom water during Holocene. Earth Planet Sci. Lett. 369, $248-259$.

Klitgaard-Kristensen, D., Sejrup, H., Haflidason, H., 2001. The last 18 kyr fluctuations in Norwegian Sea surface conditions and implications for the magnitude of climatic change: evidence from the North Sea. Paleoceanography 16, 455-467.

Kobashi, T., Menviel, L., Jeltsch-Thömmes, A., Vinther, B.M., Box, J.E., Muscheler, R. Nakaegawa, T., Pfister, P.L., Döring, M., Leuenberger, M., 2017. Volcanic influence on centennial to millennial Holocene Greenland temperature change. Sci. Rep. 7, 1441.

Koc Karpuz, N., Schrader, H., 1990. Surface sediment diatom distribution and Holocene paleotemperature variations in the Greenland, Iceland and Norwegian Sea. Paleoceanography 5, 557-580.

Koç, N., Jansen, E., 1994. Response of the high-latitude northern hemisphere to orbital climate forcing: evidence from the nordic seas. Geology 22, 523-526.

Koc, N., Jansen, E., Haflidason, H., 1993. Paleoceanographic reconstructions of surface ocean conditions in the Greenland, Iceland and Norwegian seas through the last 14 ka based on diatoms. Quat. Sci. Rev. 12, 115-140.

Kolling, H.M., Stein, R., Fahl, K., Perner, K., Moros, M., 2017. Short-term variability in late Holocene sea ice cover on the East Greenland Shelf and its driving mechanisms. Palaeogeogr. Palaeoclimatol. Palaeoecol. 485, 336-350.

Kristjánsdóttir, G.B., Moros, M., Andrews, J.T., Jennings, A.E., 2017. Holocene Mg/Ca, alkenones, and light stable isotope measurements on the outer North Iceland shelf (MD99-2269): a comparison with other multi-proxy data and sub-division of the Holocene. Holocene 27, 52-62.

Kushnir, Y., 1994. Interdecadal variations in North Atlantic sea surface temperature and associated atmospheric conditions. J. Clim. 7, 141-157.

Latif, M., Böning, C., Willebrand, J., Biastoch, A., Dengg, J., Keenlyside, N. Schweckendiek, U., Madec, G., 2006. Is the thermohaline circulation changing? J. Clim. 19, 4631-4637.

Lehner, F., Raible, C.C., Stocker, T.F., 2012. Testing the robustness of a precipitation proxy-based North Atlantic Oscillation reconstruction. Quat. Sci. Rev. 45, 85-94.

Locarnini, R.A., Mishonov, A.V., Antonov, J.I., Boyer, T.P., Garcia, H.E., Baranova, O.K. Zweng, M.M., Paver, C.R., Reagan, J.R., Johnson, D.R., Hamilton, M., Seidov, D., 2013. In: Levitus, S.E., Mishonov, A.T.E. (Eds.), World Ocean Atlas 2013, Volume 1: Temperature. NOAA Atlas NESDIS 73, p. 40.

Marchal, O., Cacho, I., Stocker, T.F., Grimalt, J.O., Calvo, E., Martrat, B., Shackleton, N., Vautravers, M., Cortijo, E., van Kreveld, S., 2002. Apparent long-term cooling of the sea surface in the northeast Atlantic and Mediterranean during the Holocene. Quat. Sci. Rev. 21, 455-483.

Martin, T., Wadhams, P., 1999. Sea-ice flux in the east Greenland current. Deep Sea Res. Part II Top. Stud. Oceanogr. 46, 1063-1082.

Mauritzen, C., 1996. Production of dense overflow waters feeding the North Atlantic across the Greenland-Scotland Ridge. Part 1: evidence for a revised circulation scheme. Deep-Sea Res. Part I Oceanogr. Res. Pap. 43, 769-806.

McCartney, M.S., Talley, L.D., 1982. The subpolar mode water of the North Atlantic Ocean. J. Phys. Oceanogr. 12, 1169-1188.

Miettinen, A., Divine, D., Koc, N., Godtliebsen, F., Hall, I.R., 2012. Multicentennial variability of the sea surface temperature gradient across the subpolar North Atlantic over the last 2.8 kyr. J. Clim. 25, 4205-4219.

Miettinen, A., Divine, D.V., Husum, K., Koc, N., Jennings, A., 2015. Exceptional ocean surface conditions on the SE Greenland shelf during the Medieval Climate Anomaly. Paleoceanography 30, 1657-1674.

Miklasz, K.A., Denny, M.W., 2010. Diatom sinkings speeds: improved predictions and insight from a modified Stokes' law. Limnol. Oceanogr. 55, 2513-2525.

Moffa-Sánchez, P., Born, A., Hall, I.R., Thornalley, D.J., Barker, S., 2014. Solar forcing of North Atlantic surface temperature and salinity over the past millennium. Nat Geosci. 7, 275.

Moossen, H., Bendle, J., Seki, O., Quillmann, U., Kawamura, K., 2015. North Atlantic Holocene climate evolution recorded by high-resolution terrestrial and marine biomarker records. Quat. Sci. Rev. 129, 111-127.

Nesje, A. Lie, Ø., Dahl, S.O., 2000. Is the North Atlantic Oscillation reflected in Scandinavian glacier mass balance records? J. Quat. Sci.: Published for the Quaternary Res. Association 15, 587-601.

Oksman, M., Weckström, K., Miettinen, A., Juggins, S., Divine, D.V., Jackson, R., Telford, R., Korsgaard, N.J., Kucera, M., 2017. Younger Dryas ice margin retreat triggered by ocean surface warming in central-eastern Baffin Bay. Nat. Commun. 8, 1017.

Olsen, J., Anderson, N.J., Knudsen, M.F., 2012. Variability of the north Atlantic oscillation over the past 5,200 years. Nat. Geosci. 5, 808 .

Orme, L.C., Charman, D.J., Reinhardt, L., Jones, R.T., Mitchell, F.J., Stefanini, B.S., Barkwith, A., Ellis, M.A., Grosvenor, M., 2017. Past changes in the North Atlantic storm track driven by insolation and sea-ice forcing. Geology 45, 335-338.

Ortega, P., Lehner, F., Swingedouw, D., Masson-Delmotte, V., Raible, C.C., Casado, M., Yiou, P., 2015. A model-tested North Atlantic Oscillation reconstruction for the past millennium. Nature 523, 71.

Orvik, K.A., Niiler, P., 2002. Major pathways of Atlantic water in the northern north Atlantic and nordic seas toward Arctic. Geophys. Res. Lett. 29.

Perner, K., Moros, M., Lloyd, J.M., Jansen, E., Stein, R., 2015. Mid to late Holocene strengthening of the East Greenland Current linked to warm subsurface Atlantic water. Quat. Sci. Rev. 129, 296-307.

Pollard, R., Read, J., Holliday, N., Leach, H., 2004. Water masses and circulation pathways through the Iceland Basin during Vivaldi 1996. J. Geophys. Res. Oceans 109.

Ran, L., Jiang, H., Knudsen, K.L., Eiríksson, J., 2011. Diatom-based reconstruction of palaeoceanographic changes on the North Icelandic shelf during the last millennium. Palaeogeogr. Palaeoclimatol. Palaeoecol. 302 , 109-119.

Rashid, H., Piper, D.J., Lazar, K.B., McDonald, K., Saint-Ange, F., 2017. The Holocene Labrador Current: changing linkages to atmospheric and oceanographic forcing factors. Paleoceanography 32, 498-510.

Rasmussen, S.O., Vinther, B.M., Clausen, H.B., Andersen, K.K., 2007. Early Holocene climate oscillations recorded in three Greenland ice cores. Quat. Sci. Rev. 26, 1907-1914.

Rasmussen, T.L. Thomsen, E. Skirbekk, K. Ślubowska-Woldengen, M. Kristensen, D.K., Koç, N., 2014. Spatial and temporal distribution of Holocene temperature maxima in the northern Nordic seas: interplay of Atlantic-, Arcticand polar water masses. Quat. Sci. Rev. 92, 280-291.

Rasmussen, T.L., Thomsen, E., Troelstra, S.R., Kuijpers, A., Prins, M.A., 2002. Millennial-scale glacial variability versus Holocene stability: changes in planktic and benthic foraminifera faunas and ocean circulation in the North Atlantic during the last 60000 years. Mar. Micropaleontol. 47, 143-176.

Reimer, P.J., Bard, E., Bayliss, A., Beck, J.W., Blackwell, P.G., Ramsey, C.B., Buck, C.E., Cheng, H., Edwards, R.L., Friedrich, M., 2013. IntCal13 and Marine13 radiocarbon age calibration curves $0-50,000$ years cal BP. Radiocarbon 55, 1869-1887.

Renssen, H., Goosse, H., Fichefet, T., Brovkin, V., Driesschaert, E., Wolk, F., 2005. Simulating the Holocene climate evolution at northern high latitudes using a coupled atmosphere-sea ice-ocean-vegetation model. Clim. Dynam. 24, 23-43.

Repschläger, J., Garbe-Schönberg, D., Weinelt, M., Schneider, R., 2017. Holocene evolution of the North Atlantic subsurface transport. Clim. Past 13, 333

Rimbu, N., Lohmann, G., Kim, J.H., Arz, H., Schneider, R., 2003. Arctic/North Atlantic Oscillation signature in Holocene sea surface temperature trends as obtained from alkenone data. Geophys. Res. Lett. 30.

Risebrobakken, B., Jansen, E., Andersson, C., Mjelde, E., Hevrøy, K., 2003. A highresolution study of Holocene paleoclimatic and paleoceanographic changes in the Nordic Seas. Paleoceanography 18.

Risebrobakken, B., Moros, M., Ivanova, E.V., Chistyakova, N., Rosenberg, R., 2010. Climate and oceanographic variability in the SW barents sea during the Holocene. Holocene 20, 609-621.

Rodwell, M.J., Rowell, D.P., Folland, C.K., 1999. Oceanic forcing of the wintertime north Atlantic oscillation and European climate. Natura (Hoogwoud) 398, 320.

Rudels, B., Fahrbach, E., Meincke, J., Budéus, G., Eriksson, P., 2002. the East Greenland current and its contribution to the Denmark Strait Overflow. ICES J. Mar. Sci. 59, 1133-1154.

Sarnthein, M., Kreveld, v.S., Erlenkeuser, H., Grootes, P., Kucera, M., Pflaumann, U., Schulz, M., 2003. Centennial-to-millennial-scale periodicities of Holocene climate and sediment injections off the western Barents shelf, 75 N. Boreas 32 447-461.

Sarthou, G., Timmermans, K.R., Blain, S., Tréguer, P., 2005. Growth physiology and fate of diatoms in the ocean: a review. J. Sea Res. 53, 25-42.

Schrader, H., Gersonde, R., 1978. Diatoms and silicoflagellates. In: Zachariasse, et al. (Eds.), Microplaeontological Counting Methods and Techniques-an Excercise on an Eight Metres Section of the Lower Pliocene of Capo Rossello. Sicily. Utrecht Micropal. Bull, vol. 17, pp. 129-176.

Seager, R., Kushnir, Y., Visbeck, M., Naik, N., Miller, J., Krahmann, G., Cullen, H., 2000. Causes of Atlantic Ocean climate variability between 1958 and 1998. J. Clim. 13, 2845-2862.

Seidenkrantz, M.-S., Aagaard-Sørensen, S., Sulsbrück, H., Kuijpers, A., Jensen, K.G., Kunzendorf, H., 2007. Hydrography and climate of the last 4400 years in a SW Greenland fjord: implications for Labrador Sea palaeoceanography. Holocene 17, 387-401.

Seidenkrantz, M.-S., Roncaglia, L., Fischel, A., Heilmann-Clausen, C., Kuijpers, A., Moros, M., 2008. Variable North Atlantic climate seesaw patterns documented by a late Holocene marine record from Disko Bugt, West Greenland. Mar. Micropaleontol. 68, 66-83.

Seierstad, I.A., Bader, J., 2009. Impact of a projected future Arctic sea ice reduction 
on extratropical storminess and the NAO. Clim. Dynam. 33, 937.

Sejrup, H.P., Seppä, H., McKay, N.P., Kaufman, D.S., Geirsdóttir, Á., de Vernal, A. Renssen, H., Husum, K., Jennings, A., Andrews, J.T., 2016. North AtlanticFennoscandian Holocene climate trends and mechanisms. Quat. Sci. Rev. 147, $365-378$.

Serreze, M.C., Carse, F., Barry, R.G., Rogers, J.C., 1997. Icelandic low cyclone activity: climatological features, linkages with the NAO, and relationships with recent changes in the Northern Hemisphere circulation. J. Clim. 10, 453-464.

Sicre, M.-A., Weckström, K., Seidenkrantz, M.-S., Kuijpers, A., Benetti, M., Massé, G., Ezat, U., Schmidt, S., Bouloubassi, I., Olsen, J., 2014. Labrador current variability over the last 2000 years. Earth Planet Sci. Lett. 400, 26-32.

Sicre, M.-A., Yiou, P., Eiríksson, J., Ezat, U., Guimbaut, E., Dahhaoui, I., Knudsen, K.-L., Jansen, E., Turon, J.-L., 2008. A 4500-year reconstruction of sea surface temperature variability at decadal time-scales off North Iceland. Quat. Sci. Rev. 27, 2041-2047.

Solignac, S., de Vernal, A., Hillaire-Marcel, C., 2004. Holocene sea-surface conditions in the North Atlantic-contrasted trends and regimes in the western and eastern sectors (Labrador Sea vs. Iceland Basin). Quat. Sci. Rev. 23, 319-334.

Solignac, S., Grelaud, M., de Vernal, A., Giraudeau, J., Moros, M., McCave, I.N., Hoogakker, B., 2008. Reorganization of the upper ocean circulation in the midHolocene in the northeastern Atlantic. Canadian J. Earth Sci. 45, 1417-1433.

Sundqvist, H.S., Kaufman, D.S., McKay, N., Balascio, N., Briner, J., Cwynar, L., Sejrup, H., Seppä, H., Subetto, D., Andrews, J., 2014. Arctic Holocene proxy climate database-new approaches to assessing geochronological accuracy and encoding climate variables. Clim. Past 10, 1605-1631.

Taylor, A.H., Stephens, J.A., 1998. the North Atlantic oscillation and the latitude of the Gulf Stream. Tellus Dyn. Meteorol. Oceanogr. 50, 134-142.

Tegzes, A.D., Jansen, E., Lorentzen, T., Telford, R.J., 2017. Northward oceanic heat transport in the main branch of the Norwegian Atlantic Current over the late Holocene. Holocene 27, 1034-1044.

Telesiński, M.M., Spielhagen, R.F., Bauch, H.A., 2014. Water mass evolution of the Greenland Sea since late glacial times. Clim. Past 10, 123-136.

ter Braak, C.J., Juggins, S., 1993. Weighted averaging partial least squares regression (WA-PLS): an improved method for reconstructing environmental variables from species assemblages. In: Twelfth International Diatom Symposium. Springer, pp. 485-502.

Thornalley, D.J., Elderfield, H., McCave, I.N., 2009. Holocene oscillations in temperature and salinity of the surface subpolar North Atlantic. Nature 457, 711.

Trachsel, M., Telford, R.J., 2016. Estimating unbiased transfer-function performances in spatially structured environments. Clim. Past 12, 1215-1223.

Trouet, V., Esper, J., Graham, N.E., Baker, A., Scourse, J.D., Frank, D.C., 2009. Persistent positive North Atlantic Oscillation mode dominated the medieval climate anomaly. Sciences 324, 78-80.
Turner, J.T., 2002. Zooplankton fecal pellets, marine snow and sinking phytoplankton blooms. Aquat. Microb. Ecol. 27, 57-102.

Våge, K., Pickart, R.S., Spall, M.A., Valdimarsson, H., Jónsson, S., Torres, D.J. Østerhus, S., Eldevik, T., 2011. Significant role of the North Icelandic Jet in the formation of Denmark Strait overflow water. Nat. Geosci. 4, 723.

Van Nieuwenhove, N., Baumann, A, Matthiessen, J., Bonnet, S., de Vernal, A. 2016. Sea surface conditions in the southern Nordic Seas during the Holocene based on dinoflagellate cyst assemblages. Holocene 26, 722-735.

Van Nieuwenhove, N., Knudsen, M.F., Pearce, C., Røy, H., Seidenkrantz, M.-S., 2018. Meltwater and seasonality influence on subpolar Gyre circulation during the Holocene. Palaeogeogr. Palaeoclimatol. Palaeoecol. 502, 104-118.

Vare, L.L., Masse, G., Gregory, T.R., Smart, C.W., Belt, S.T., 2009. sea Ice variations in the central canadian Arctic Archipelago during the Holocene. Quat. Sci. Rev. 28, 1354-1366.

Vihma, T., 2014. Effects of Arctic sea ice decline on weather and climate: a review. Surv. Geophys. 35, 1175-1214.

Vinther, B.M., Buchardt, S.L., Clausen, H.B., Dahl-Jensen, D., Johnsen, S.J., Fisher, D. Koerner, R., Raynaud, D., Lipenkov, V., Andersen, K., 2009. Holocene thinning of the Greenland ice sheet. Nat 461, 385.

Visbeck, M., Chassignet, E.P., Curry, R.G., Delworth, T.L., Dickson, R.R., Krahmann, G., 2003. The Ocean's Response to North Atlantic Oscillation Variability, The North Atlantic Oscillation: Climatic Significance and Environmental impact pp. 113-145.

Werner, K., Müller, J., Husum, K., Spielhagen, R.F., Kandiano, E.S., Polyak, L., 2016 Holocene sea subsurface and surface water masses in the Fram Strait-Comparisons of temperature and sea-ice reconstructions. Quat. Sci. Rev. 147, 194-209.

Werner, K., Spielhagen, R.F., Bauch, D., Hass, H.C., Kandiano, E., 2013. Atlantic Water advection versus sea-ice advances in the eastern Fram Strait during the last 9 ka: Multiproxy evidence for a two-phase Holocene. Paleoceanography 28, $283-295$.

Woodgate, R.A., Fahrbach, E., Rohardt, G., 1999. Structure and transports of the East Greenland Current at $75 \mathrm{~N}$ from moored current meters. J. Geophys. Res. Oceans 104, 18059-18072.

Wright, W.R., Worthington, L.V., 1970. The Water Masses of the North Atlantic Ocean, a Volumetric Census of Temperature and Salinity. American Geographical Society.

Yang, S., Christensen, J.H., 2012. Arctic sea ice reduction and European cold winters in CMIP5 climate change experiments. Geophys. Res. Lett. 39.

Zweng, M.M., Reagan, J.R., Antonov, J.I., Locarnini, R.A., Mishonov, A.V., Boyer, T.P., Garcia, H.E., Baranova, O.K., Johnson, D.R., Seidov, D., Biddle, M.M., 2013. In: Levitus, S. (Ed.), World Ocean Atlas 2013, Vol. 2: Salinity. A. Mishonov Technical Ed.; NOAA Atlas NESDIS 74, 39 pp. 